HAJDÚ ATTILA

\title{
Ailios Aristeidés Athéna istennőhöz írt prózahimnusza (Or. 37.)
}

Ailios Aristeidés a második szofisztika egyik legsokoldalúbb prózaírója. Jelen kötetben az Athénához írt prózahimnuszának magyar fordítását tesszük közzé. ${ }^{1}$

Kulcsszavak: Ailios Aristeidés, prózahimnusz, Athéna, vallástörténet, második szofisztika

A Platón Lakomájában olvasható Erós-enkómiontól eltekintve Ailios Aristeidés prózahimnuszai az elsők, amelyek teljes egészében fennmaradtak a kéziratos hagyományban, s a későbbi szónokok különösen Menandros Rhétór - méltatásának köszönhetően a müfaj kanonikus mintapéldányaivá váltak. Az, hogy Aristeidés a költői hymnosok helyébe prózai 'hitszónoklat' gyanánt az isteneket magasztaló beszédet állította, a korszakban nem értékelhető egyedülálló és teljesen formabontó vállalkozásnak. Már a hellénisztikus korból ismerünk olyan, az istenségről, attribútumairól és tetteiről szóló prózai aretalogiákat, amelyek a retorika hagyományainak megfelelően az enkómion müfajába sorolhatók. ${ }^{2}$

A prózai dicshimnuszok és a retorika szoros kapcsolatára utalhat az is, hogy a római szónoklattan nagymestere, Quintilianus az Institutio Oratoria 'de laude et vituperatione' ('Dicséret és feddés') fejezetében már

\footnotetext{
${ }^{1}$ A publikáció elkészítését az MTA-SZTE Antikvitás és Reneszánsz: Források és Recepció Kutatócsoport (TK2016-126) támogatta.

${ }^{2}$ Ld. pl. Isis aretalogiáját a thrák Maróneiából: PAPANIKOLAOU (2009: 59-70).
} 
egy évszázaddal Aristeidés müködése előtt, tanácsokkal látja el olvasóit arra vonatkozóan, hogyan is lehet jól beszélni az istenségről. ${ }^{3}$

$\mathrm{Az}$ istenek prózai magasztálásának topikája egy bizonyos Alexandros rhétort is fogalkoztatta, aki valószínüleg már Aristeidés kor-

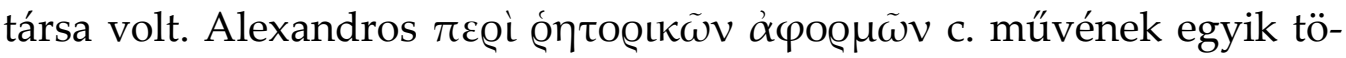
redéke (AПO ПО $\Omega$ N $\triangle$ EI THEON EПAINEIN) sorra veszi azokat a szempontokat, amelyek alapján dicsőíteni kell az istenséget. Alexandros javaslatai a következők: az isten születése és életkora, az őt tisztelő népek száma, az isten típusa - hogy égi, asztrális vagy tengeri istenről vane szó -, a kultusza helyszínei, a védnöki szerepköre, a találmányai, a tettei, az istenek körében elfogalt státusza, valamint az emberiséghez füzödő viszonya - különösen a philanthrópiája. ${ }^{4}$

A Kr. u. 2. század középen müködő Ailios Aristeidés tíz fennmaradt prózahimnuszát (Or. 37-46) élete különböző szakaszaiban alkotta: nyolcat egy-egy istenhez - Athénához, Hérakléshez, Dionysoshoz, Zeushoz, Sarapishoz, Poseidónhoz, Asklépioshoz és annak fiaihoz címezte, a további kettőt pedig szakrális és szent helyszíneknek - az Asklépios szentélynél csörgedező forrásnak és az Égei-tengernek szentelte.

Hogy vallásos témájú beszédei az említett Menandros Rhétór mellett Libanios és Iulianos számára is mintaadóvá válhattak és csodálókra találtak bennük, egyrészt a második szofisztika közegének, a szerző klasszikus irodalom alapos ismeretére épülő műveltségének, másrészt a Sarapis-himnusz elején megfogalmazott módszertani prooimionjának (Or. 45, 1-13.) volt köszönhető. Ebben fejti ki részletesen, hogy miért alkalmasabb az istenek dicsőítésére a próza a költészetnél -

\footnotetext{
${ }^{3}$ Quint. Inst. 3, 7, 7-9: Verum in deis generaliter primum maiestatem ipsius eorum naturae venerabimur, deinde proprie vim cuiusque et inventa quae utile aliquid hominibus attulerint. Vis ostendetur, ut in Iove regendorum omnium, in Marte belli, in Neptuno maris: inventa, ut artium in Minerva, Mercurio litterarum, medicinae Apolline, Cerere frugum, Libero vini. Tum si qua ab iis acta vetustas tradidit, commemoranda. Addunt etiam dis honorem parentes, ut si quis sit filius Iovis, addit antiquitas, ut iis qui sunt ex Chao, progenies quoque, ut Apollo ac Diana Latonae. Laudandum in quibusdam quod geniti inmortales, quibusdam quod inmortalitatem virtute sint consecuti: quod pietas principis nostri praesentium quoque temporum decus fecit.

${ }^{4}$ PARKER (2016: 69, 8. jz.)
} 
mindezt úgy, hogy a költészet tagadhatatlan érdemeit sem vitatja. Így amikor a mysiai rhétor prózahimnuszaiban a saját vallásos meggyőződését hangoztatja és az istenek és az emberek között közvetítő/prófétikus szerepben mutatja magát, egyúttal a hosszú múltra visszatekintő, 'isteni' és 'költői' közötti polémiában is állást kívánt foglalni. Beszédei formailag az enkómionokat, szerkesztésükben a költői himnuszokat követik. Nem véletlen, hogy a szerző prózahimnuszaira egyidejűleg használja a logos, a hymnos és az enkómion megnevezéseket.

$\mathrm{Az}$ aristeidési prózahimnuszok további közös jellemzője az egy- és többistenhit határán mozgó henoteizmus: Aristeidés az összes többi isten fölé helyezi azt az istenséget, akit éppen dicsér. Lenz találó felvetése szerint Aristeidés saját korának új hihívásaira, - többek között a már ébredező kereszténységre - reagált ezekben a himnuszokban. Nézete szerint bár Aristeidés nem utal expressis verbis a kereszténységre, Athénához írott himnuszában legszembetünőbb a kereszténységgel szembeni fellépése. Aristeidés a pogány isteneket az egy isten szerepeiben ábrázolja, hogy alássa a kereszténység monoteizmusának 'újszerüségét'. ${ }^{5}$

Mindennek köszönhető, hogy az Athéna-himnusz tankönyvszerü tömörséggel foglalja össze az istennővel kapcsolatos irodalmi, mitológiai és filozófiatörténeti hagyományt. A következőkben a himnusz fordítását adom közre magyarázó jegyzetekkel ${ }^{6}$. A fordítás a lipcsei kiadás alapján készült.7 A klasszikus szerzők és müveik esetében az LSJ (Liddell-ScottJones, A Greek-English Lexicon) és az OLD (Oxford Latin Dictionary) rövidítésrendszerét, egyes szerzőknél a szakirodalomban bevett rövidítéseket követtem. A fordítás ellenőrzéséért és értékes javaslataiért Nagyillés Jánosnak tartozom köszönettel.

\section{Források}

DINDORF 1829 = W. DINDORF, Aristides, vol. 1, Leipzig, 1829.

\footnotetext{
${ }^{5}$ LENZ (1963: 329-347).

6 A jegyzetek írásánál KEIL (1898), GOEKEN (2012) és JÖHRENS (1981, 1. kötet) kommentárjára támaszkodtam.

7 DINDORF (1829: 12-28).
} 


\section{Felhasznált irodalom}

BAUMgART 1874 H. BAUMgarT, Aelius Aristides als Repräsentant der Sophistischen Rhetorik des Zweiten Jahrhunderts der Kaiserzeit, Leipzig, 1874.

GOEKEN 2012 J. GOEKEN, Aelius Aristide et la rhétorique de l'hymne en prose, Turnhout, 2012.

JÖHrEns 1981 G. JÖHrEns, Aelius Aristides, Der Athenahymnus des Ailios Aristeides: Mit einem Anhang zum Höhenkult der Athena und Testimonien zur Allegorischen Deutung der Athena, 1-2. Band, Bonn, 1981.

KEIL 1898

B. KeIL, Aelius Aristides, Aelii Aristidis Smyrnaei Quae Supersunt Omnia, Berolini, 1898.

LENZ 1963

F. W. LENZ, Der Athenahymnos des Aristides, Rivista di cultura classica e medievale, 5 (1963), 329-347.

PAPANIKOLAOU 2009 D. PAPANIKOLAOU, The Aretalogy of Isis from Maroneia and the Question of Hellenistic "asianism," Zeitschrift für Papyrologie und Epigraphik, 168 (2009), 59-70.

PARKER 2016

R. PARKER, Religion in the Prose Hymns, in: H. Nesselrath H - D. Russell - M. Trapp (eds.), In Praise of Asclepius: Aelius Aristides, Selected Prose Hymns, Tübingen, 2016, 67-88.

PERNOT 2007

L. PERnOt, Le livre grec au IIe siècle ap. J.-C. à partir de l'œuvre d'Ælius Aristide, Comptes rendus des séances de l'Académie des Inscriptions et Belles-Lettres, 151 (2007), 933-965.

ROBERT 1969

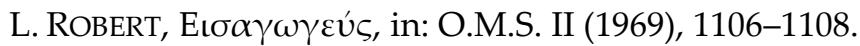





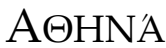

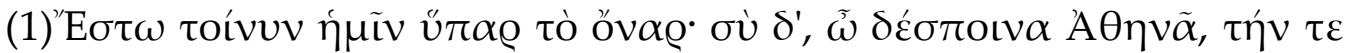

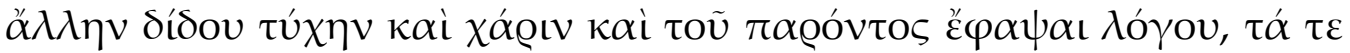

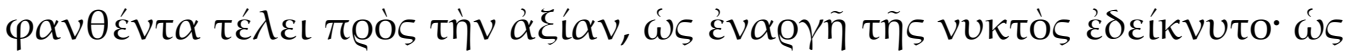

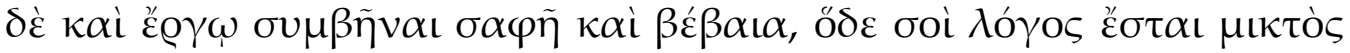

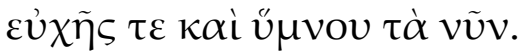

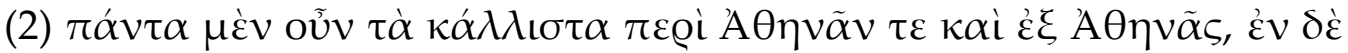

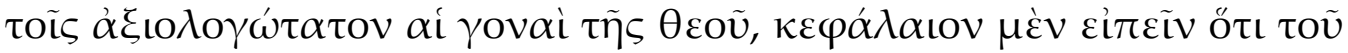

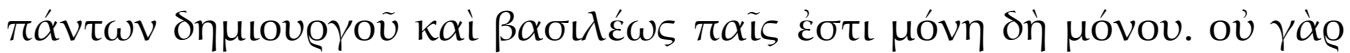

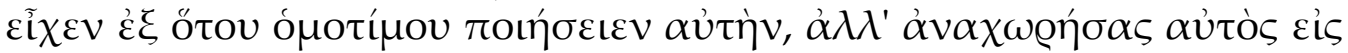

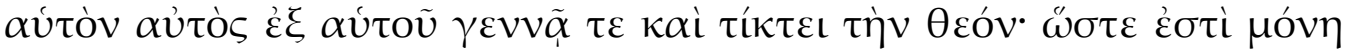

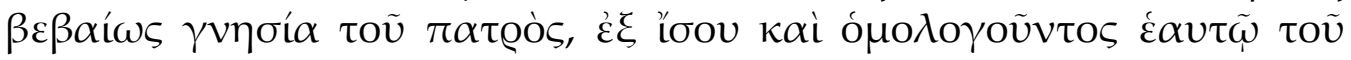

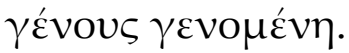

1 Számos kéziratban az Athéna-himnuszt a MANTEイTOI („Látnoki” / „jóslás útján elrendelt beszédek") cím előzi meg, amely Aristeidés e prózahimnuszokat tartalmazó

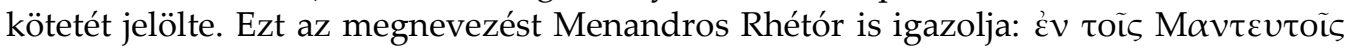

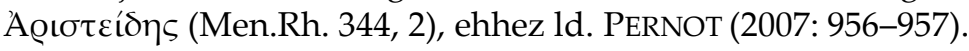

2 A bevezető mondat félreérthetetlenül arra utal, hogy egy álom inspirálta Aristeidés Athéna-himnuszát. A szónok Athéna istennő álomlátására is hivatkozik (ld. a 29-es caputot:

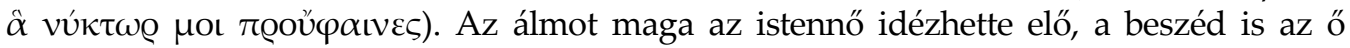
megrendelése készült, amelyet a szónok már álmában is előadhatott. Aristeidésnél az

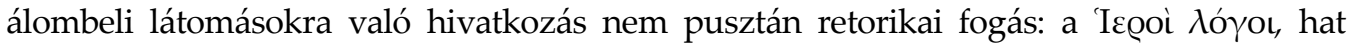
könyvből álló című müve jól illusztrálja, hogy a folytonosan betegeskedő szónok felépülése reményében - milyen fontos szerepet tulajdonított az álmoknak és Asklépios álombeli sugallatainak.

Az ókori irodalom áttekintése után kiderül, hogy Athénát nem sorolhatjuk a tipikus álomistenségek közé - egy kivétel mégis akad: Pindarosnál Athéna Bellerophón álmában megjelenő jósistennő (Pi. O. 13, 64). Miután Bellerophón az istennő oltáránál töltötte az éjszakát (incubatio), álmában gyeplőt kapott, amivel megszelídítheti Pégasost. (Pi. O. 13, 75

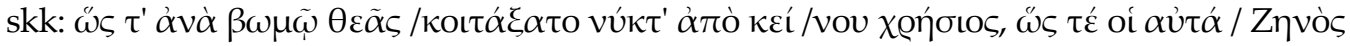

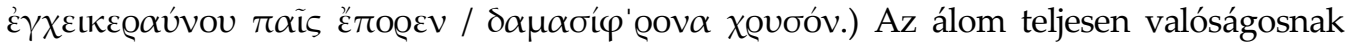

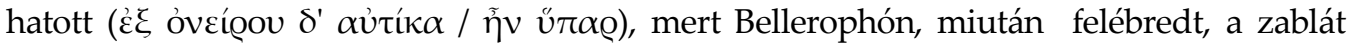
maga mellett találta. Ezután hálából oltárt emelt Athéna Hippia tiszteletére.

További szöveghelyek Athéna álombeli feltünéséhez 1) védő, segítő és támogatást adó szerepben: pl. a fiáért aggódó Pénelopénak Iphthimé alakjában képmást küldött, hogy enyhítse Pénelopé bánatát: Hom. Od. 4, 796sk., Nausikaa előtti epifániája Od. 6, 22 skk. ; 2) Athénnal kapcsolatos történetekben: pl. Athéna Hygieia szobrának felállítása az athéni Akropolison szintén egy, Athéna által küldött álomra vezethető vissza: Plu. Per. 13, 7.; 3) Törvényhozó istennő szerepkörben: Athéna a dél-itáliai Lokroi törvényhozójának, Zaleukosnak álmában fedte fel a törvényeket (Schol. Pi. O. 10,17). Athéna további álombeli szerepéhez ld. részletesebben JÖHRENS (1981, 1 kötet: 31-37). 


\section{ATHÉNA ${ }^{1}$}

[Prooimion] (1) Nosza, az álmunk legyen immáron valóság!² Ó Athéna úrnő, adj még szerencsét és kegyet is, fordulj mostani beszédemhez, ${ }^{3} \mathrm{~s}$ érdeme szerint váltsd valóra a látomásokat úgy, ahogy elevenen feltárulkoztak az éjszaka során. Hogy ez valóban világosan és biztosan végbemenjen, legyen itt e beszéd számodra, mely az imádság és a himnusz elegye. ${ }^{4}$

[Athéna születése] (2) Noha minden gyönyörü, ami Athénát érinti és Athénától ered, mégis a leginkább figyelemre méltó az istennő születése. Legfőképpen ${ }^{5}$ azért, mert Athéna minden dolog megalkotójának ${ }^{6}$ és királyának $^{7}$ egyetlen lánygyermeke, aki egyedül tőle származik. ${ }^{8}$ Valójában nem akadt senki [vele] rangban egyenlö, akiből megalkothatta volna az istennőt, így hát elvonult magába, ${ }^{9}$ hogy saját magából megalkossa és világra hozza az istennőt. Athéna tehát az egyedüli törvényes lánya apjának, származása apjáéval azonos és megegyező volt.

\footnotetext{
${ }^{3}$ Aristeidés prózahimnuszát legtöbbször logosnak nevezi.

4 BAUMGART (1874: 80-81, 71. jz) szerint Aristeidés hymnost az istennőhöz intézett dicsőítő beszédre, míg az euchét a beszéd bevezetőjébe és zárszavába belefoglalt könyörgésekre használja.

${ }^{5}$ A $\kappa \varepsilon \varphi \alpha ́ \lambda \alpha ı$ s szójáték, utalás Zeus fejére, ahonnan Athéna megszületik.

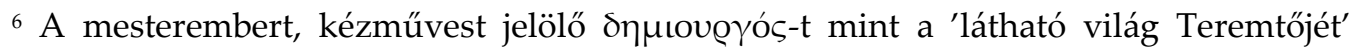
először Platón használja: Pl. Ti. 28 a.

7 Vagyis Zeustól, vö. Hom. Il. 5, 880.

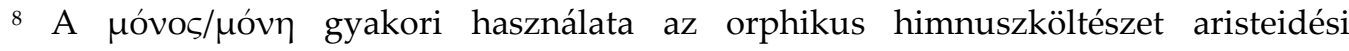
himnuszokra gyakorolt hatását mutatja.

9 A sztoikus tanítás szerint az istenség magába vonul vissza az ekpyrósis során Vö. Chrysipp. Stoic. fr. 1064. és 1065.
} 


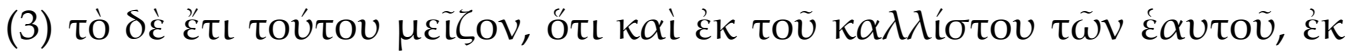

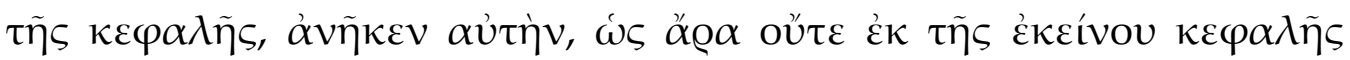

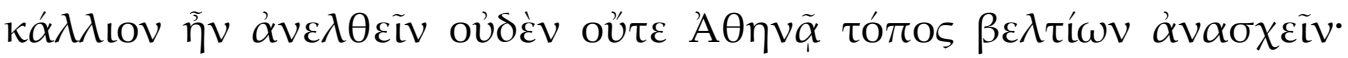

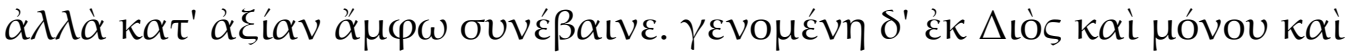

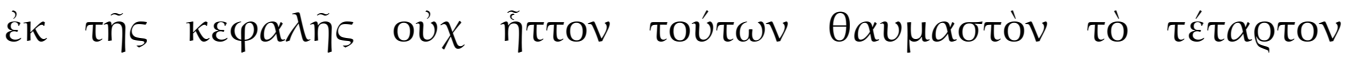

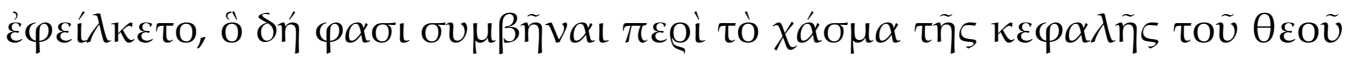

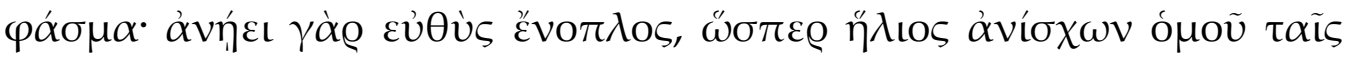

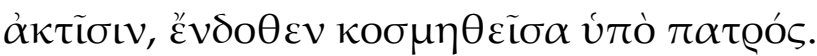

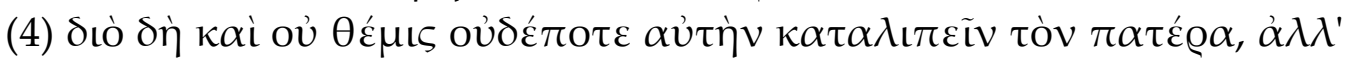

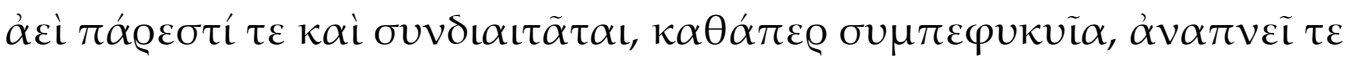

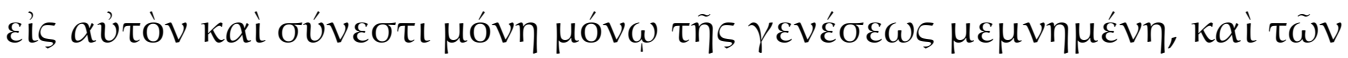

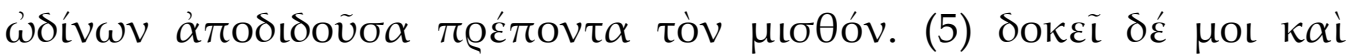

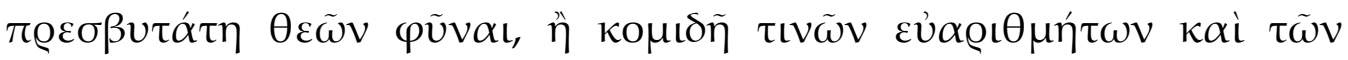

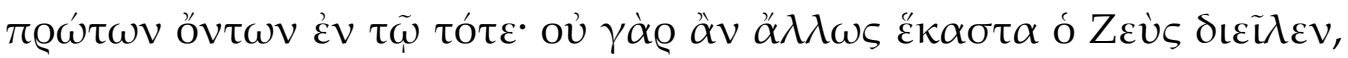

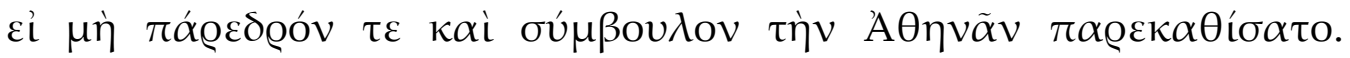

10 Homéros nem szól részletesen az istennő születésének körülményeiről, Athénát egyszerúen Zeus lányának nevezi: Vö. Hom. Il. 5, 880; Hésiodos szerint Uranos és Gaia tanácsára Zeus lenyelte első hitvesét, Métist, még mielőtt megszülhette volna Athénát, aki ezután a föisten fejéből kiszökkenve született meg: Hes. Th. 886-900, 924-926. A mítosz másik változata szerint Héphaistos fejszével felhasította Zeus fejét, hogy Athéna megszülethessen. Ez a változat Pindarosnál olvasható először (Pi. O. 7, 35 skk.), de az ábrázoló művészetben már a Kr. e. 7. század végétől ismert. Athéna születésének témája a vázafestészetben különösen a Kr. e. 6. század második negyedétől adatolható, és a Kr. e. 5. század elejéig számított népszerünek. Ezeken az ábrázolásokon többnyire Zeus, a főisten fejéből pajzzsal, lándzsával és sisakban előugró Athéna, kettő Eileithyia és kettős bárddal Héphaistos látható. A Parthenón keleti oromcsoportján az olymposi istenek társaságában a trónoló Zeusz és az éppen megszületett, de már felnőtt Athéna áll. Meglepő módon a Kr. e. 5. századi athéni vörösalakos vázafestészetben nem találunk példát Athéna születésének ábrázolására, majd a Kr. e. 4. századi etruszk tükrök díszítésénél előszeretettel nyúlnak vissza a témához.

${ }^{11}$ A pythagoreusoknál a négy az igazságosság, a tetraktys (az első négy szám együttese) a pythagoreus bölcsesség lényege, az örökké tartó természet forrása (Carm. Aur. 48), vö. Pl. Prt. 339 b.

${ }^{12}$ Athéna fegyverzetben történő születése először Stésichorosnál bukkan fel: ld. Scol. A. R. 4, 1310. Továbbá: Hom. Hymni, 28, 4-6: „maga a bölcs Zeus szülte nemes fejéből,

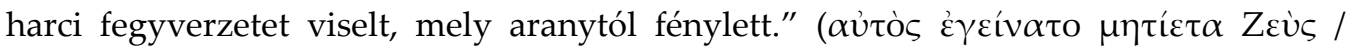

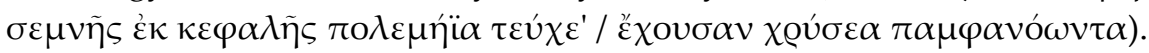


(3) Ennél is fontosabb, hogy apa a legszebb részéből, a fejéből teremtette meg az istennőt. Sem szebb nem tudott volna fejéből kipattanni, sem Athénának nem lehetett volna nemesebb hely, ahonnan előszökkenjen. Csakhogy mindkettő így ment végbe, ahogy az az istennőt meg is illeti: Zeusból született, egyedül belőle, mégpedig a fejéből. ${ }^{10}$ Még egy negyedik ${ }^{11}$ csodát is előidézett, mely nem marad el a többitől. Azt beszélik, hogy ez az istennő látványa, amikor apja feje megnyílt, hiszen onnan rögvest teljes fegyverzetben ${ }^{12}$ emelkedett $\mathrm{ki}$, mint a sugaraival együtt felkelő nap, ${ }^{13}$ ahogy apja még odabent ékesítette fel. (4) Ezért nem szabad sohasem elhagynia apját. Épp ellenkezőleg: folyton mellette van és együtt él vele, mintha összenőttek volna. ${ }^{14}$ Apjával egy ütemben lélegzik és egyedül ő az, aki csak vele áll kapcsolatban, mert emlékezik születésére, s illő bért fizet neki az azzal járó fájdalmakért.

[Az istennő tisztelete és hatalma] (5) Nézetem szerint a legidősebb ${ }^{15}$ is az istenek között, vagy legalábbis azon kevesek egyike, akik hajdanán az elsők között éltek. Máskülönben Zeus nem tudott volna szétválasztani minden egyes dolgot, ha nem Athéna ült volna az oldalán segítőként ${ }^{16}$ és tanácsadóként.

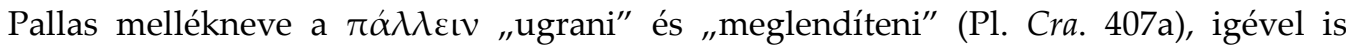
összefüggésbe hozható, epiklésise tehát apja fejéből való előugrásból és fegyvereinek meglengetésébool is levezethető. Az ábrázoló müvészetben a teljes fegyverzeten megszülető Athéna legkorábbi példája minden valószínüség szerint egy, a tenosi Xoborgóból előkerült kykládikus pithos domborművén látható (Kr. e. 680/670k.).

13 Összevetés a Nap sugaraival: az epiphania során gyakran említik a fény- vagy napsugarakat, ld. Hom. Il. 6, 513; 19, 398.

${ }_{14}$ Zeus sosincs egyedül, közvetlen környezetében időzik Kratos, Bia, Niké és Zélos vö. Hes. Th. 386.

${ }_{15} \mathrm{Az}$ életkorra való hivatkozás a himnuszokban szinte mindig előkerül (Quint. Inst. Or. 3, 7, 8: honorem ... addit antiquitas). Vö. az orphizmusban Dionysost életkora miatt dicsérik: Orph. H. 52, 6 ( $\theta \varepsilon \tilde{\omega} v$ Tá $\varepsilon \varepsilon$ : az istenek atyja), Erós Platón Lakomájában (Pl.

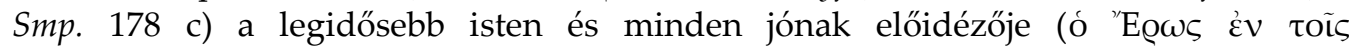

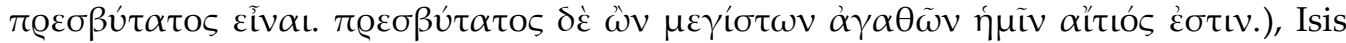

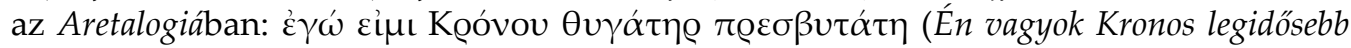
lánya: Aret. 5).

16 Athéna Zeus tanácsadója, mindig a közelében van. Vö. Sap 9, 9: a bölcsesség - (,a

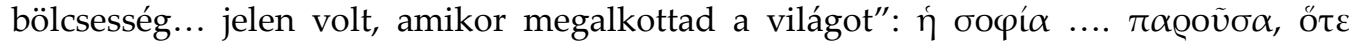

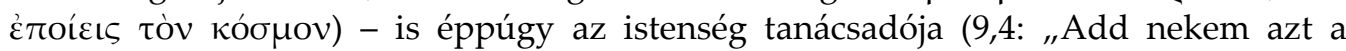

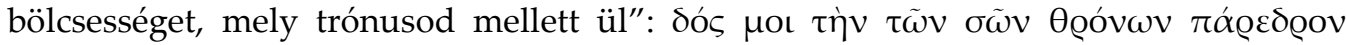
бофíav). Zeus mellett a tanácsadói szerepkört Themis (Pi. O. 8, 22,) és Diké (Plu. Alex. 52.) érdemelte ki. 


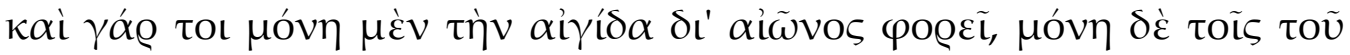

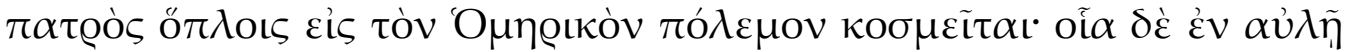

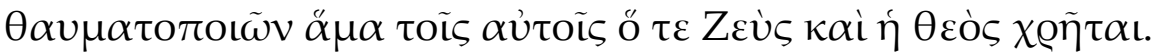

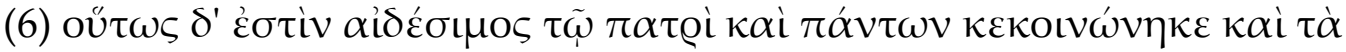

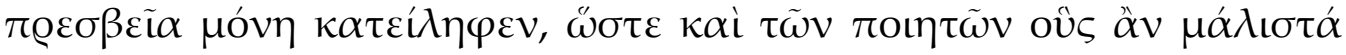

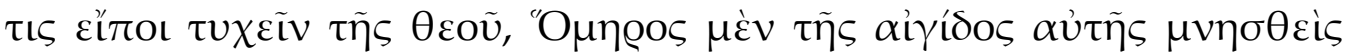

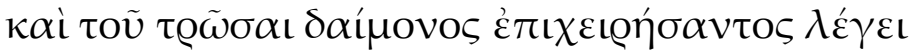

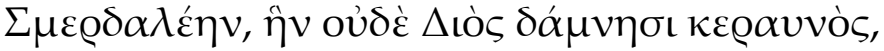

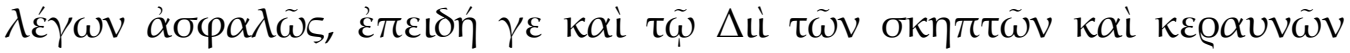

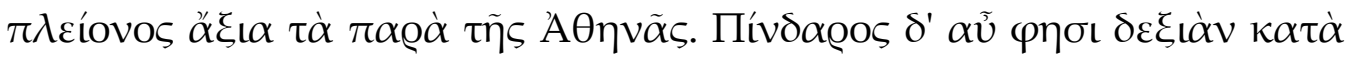

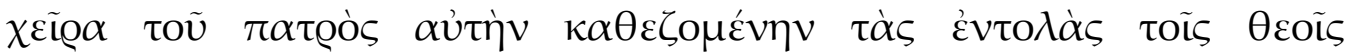

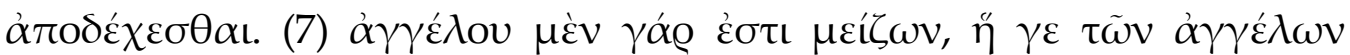

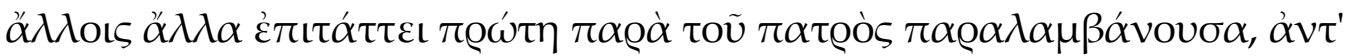

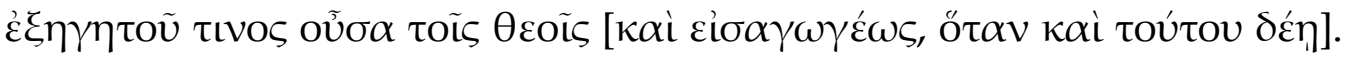

${ }^{17}$ Homérosnál Zeus Aigiochos mellett csak két isten viseli az Aigist: az egyik Athéna (Hom. Il. 21, 400), akit a képzőművészeti ábrázolásokon is csaknem mindig Aigisban látunk. A másik Apollón, aki szintén használja azt, ám csak Zeus megbízásából vö. Hom. Il. 15, 229-230.

18 Vö. Hom. Il. 387-388: „S fellegtorlaszoló Zeusz ércingét felövezve, / fegyveresen készült könnyontó háboruságra." (Ford. DEVECSERI G.) (î $\delta \dot{\varepsilon} \chi \iota \tau \tilde{\omega} v^{\prime} \varepsilon \dot{\varepsilon} \delta \tilde{v} \sigma \alpha \Delta$ iò

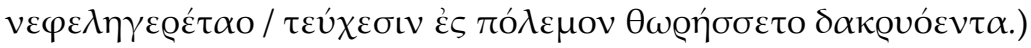

19 A Ө bűvésztől és zsonglőrtől egészen a bábjátékosig (Pl. Sph. 235 d; R. 514 b; D. 2, 19). Itt Aristeidés összeveti Zeust egy nagy csodatévővel (talán Asklépiosszal vö. Or. 39, 14.), Athénát annak segítőjével, akinek átadja bizonyos attribútumait és erejét. Továbbá a "csodatévő" a teremtés kontextusában, kozmológiai síkon is értelmezhető. Hom. Od. 4,

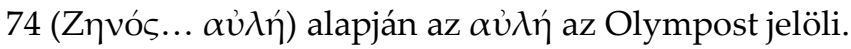

20 Arés, aki az Iliasban megtámadta az istennőt: Hom. Il. 21, 391 skk. Aristeidés egyszerüen csak daimónnak aposztrofálja Arést.

${ }^{21}$ Hom. Il. 21, 401. Ford. DEVECSERI G. 
Ő az egyetlen istennő, aki örökké Aigist visel, ${ }^{17}$ egyedül ô szerelkezik fel a homérosi harchoz apja fegyvereivel, ${ }^{18}$ és, akárcsak a csodatévők udvarában, ${ }^{19}$ Zeus és az istennő egyszerre használják azokat.

(6) Egyszóval Athéna apja szemében különösen tiszteletre méltó. Mindenben osztozott vele és egyedül ő nyerte el az elsőszülöttséggel járó előjogokat olyannyira, hogy a költők közül - akikről leginkább elmondható, hogy az istennő jóindulatában részesültek - Homéros, miután felidézte az istennő Aigisát és azt az istent, ${ }^{20}$ aki megpróbálta megsebezni Athénát, azt mondta:

„a félelemkeltőt, amit még Zeus villáma sem ver le." ${ }^{21}$

Homéros helyesen állítja ezt, mert még Zeus szemében is többet ér a mennydörgésnél és villámoknál ${ }^{22}$ is mindaz, ami Athénától ered. ${ }^{23}$ Eközben Pindaros azt mondja, hogy Athéna apja jobbján ${ }^{24}$ ül és az isteneknek címzett parancsokat veszi át. (7) Athéna ugyanis fontosabb egy hírnöknél. Ő az, aki hírnököknek egyszer ezt, máskor azt a parancsot adja. Ezeket első kézből kapja apjától. Egyfajta tolmácsa ${ }^{25}$ az isteneknek és a [beavató] ${ }^{26}$ szerepét is betölti, [ha a szükség úgy hozza].

\footnotetext{
${ }^{22}$ A mennydörgés és a villám Zeus attribútumai: Vö. Hes. Th. 504-506.

${ }^{23}$ Tudniillik az istennő bölcsessége többet ér, mint az erőszakot jelképező villámlás és mennydörgés. A motívumhoz ld. A. Pr. 211sk és 915skk.

${ }_{24}$ Pi. fr. 146. Aristeidés ezzel voltaképp egy új rangsort állít fel az Olymposon. A főisten közelében tartózkodáshoz: Hom. Il. 24, 100: "Zeusz atya mellé ült; Pallasz

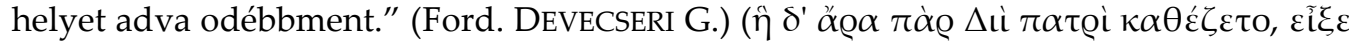

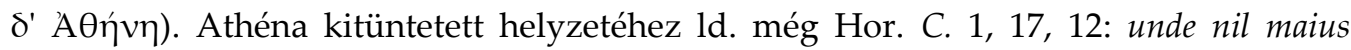
generatur ipso / nec viget quidquam simile aut secundum. / proximos illi tamen occupavit / Pallas honores (...).

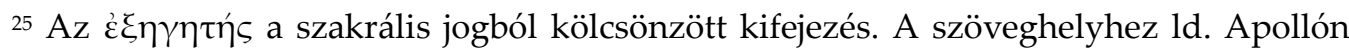
funkcióját Iulianusnál (Jul. Or. 4, 144 a): „Apollón tolmácsolja számunkra a legszebb

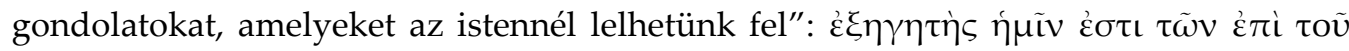

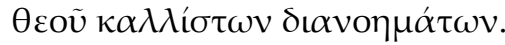

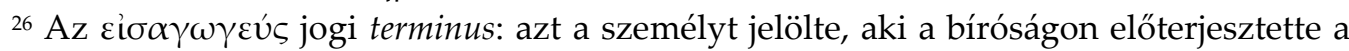
vádat. A kifejezés a Kr. u. 1-2. század fordulóján lépett ki a jogi és államjogi szférából. Itt Aristeidés Héraklésnek az Olymposra történő bevezetésére utal. A kifejezéshez ld. még a kis-ázsiai feliratos anyagot is, ahol a versenybe bevezető személyt jelöli: ld. ROBERT (1969: 1106-1108).
} 


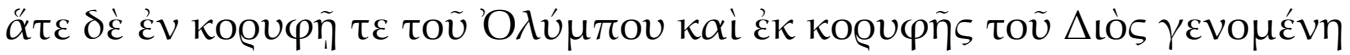

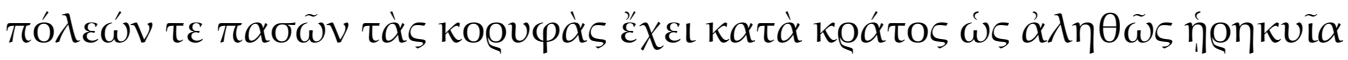

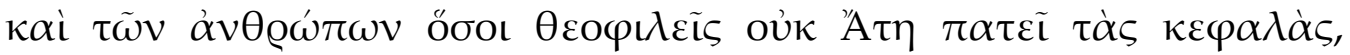

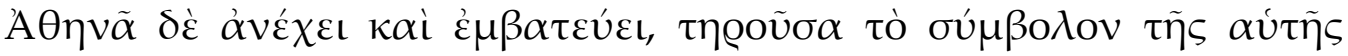

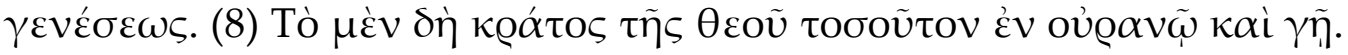

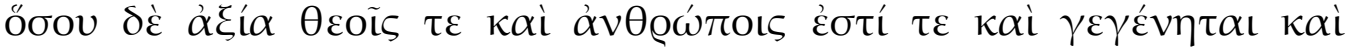

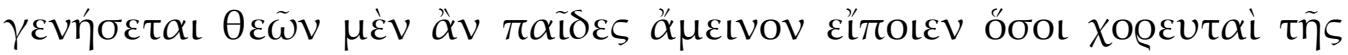

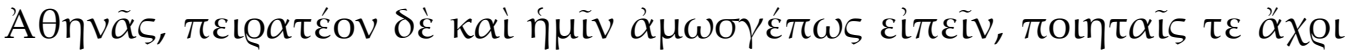

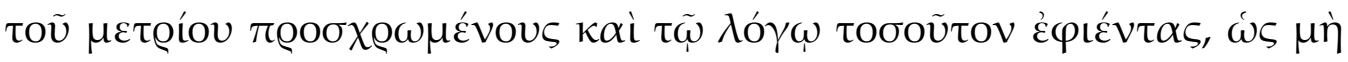

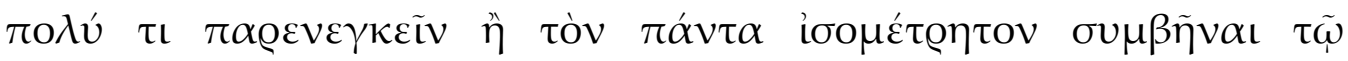
ỏveío $\alpha \tau$ เ

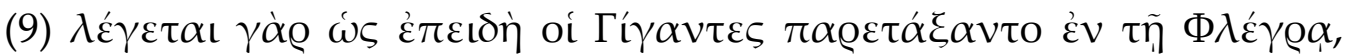

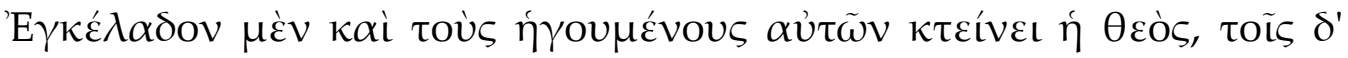

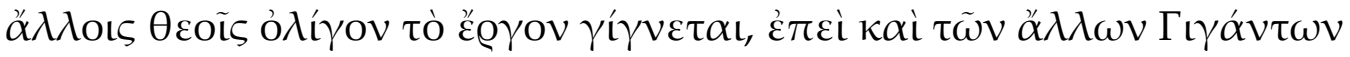

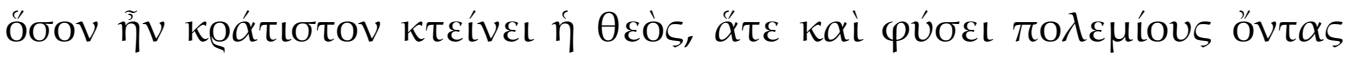

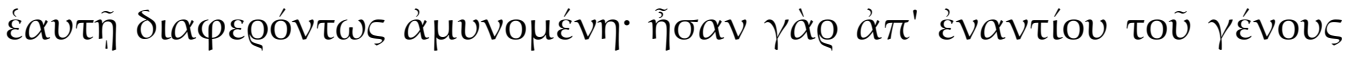

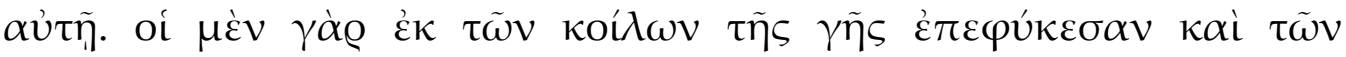

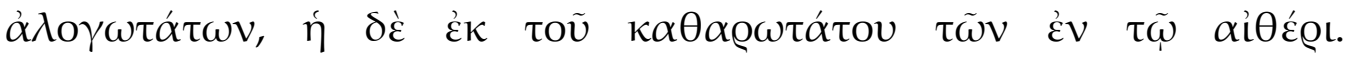

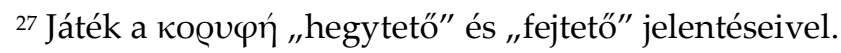

${ }^{28}$ Az istennő születésének és az Akropolisokon kialakult tiszteletének összekapcsolása. Az irodalmi források és a feliratos anyag bevonásával ld. JÖHRENS (1981, 1. kötet: 7071) és JÖHRENS (1981, 2. kötet: 359-390) részletes katalógusát.

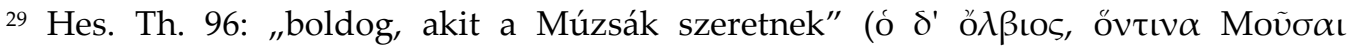

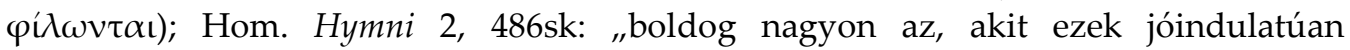

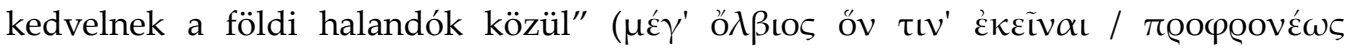
$\left.\varphi \hat{i} \lambda \omega v \tau \alpha \iota \dot{\varepsilon} \pi \iota \chi \theta o v i ́ \omega v \dot{\alpha} v \theta \varrho \omega ́ \pi \omega v^{*}\right)$.

30 Até a baj, a téveszme, pusztulás és az ostobaság istennője a görög mitológiában: Hom. Il. 19, 91-94: „Zeusznak lánya az Ártás, ő árt mindegyikünknek, / tisztelt, ám vészes; puha lábon jár, nem a földön / lép ugyanis, de fején a halandó földilakóknak, / s

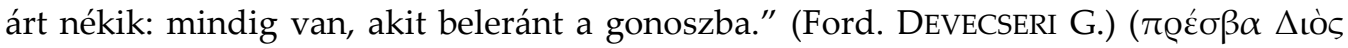

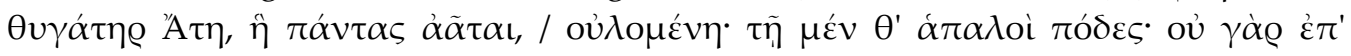

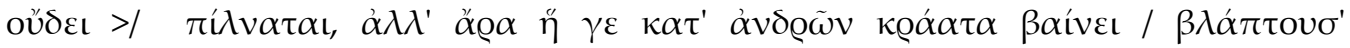

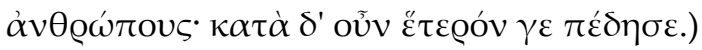

31 A védőisten összefüggésében az $\varepsilon \mu \beta \alpha \tau \varepsilon v ́ \omega$ („,belép”, ,gyakran megfordul”): A. Pers. 449 és Cratin. 321 (LIDDELL-SCOTT-JONES alapján)

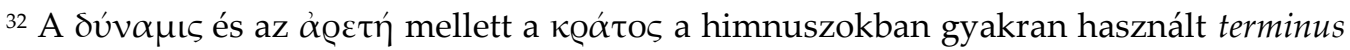
technicus, amellyel az istenség hatalmát fejezik ki. 
Mivel Athéna az Olympos csúcsán és Zeus fejéből született, ${ }^{27}$ mintha csak bevette volna, valamennyi város magaslatát birtokba veszi erejével. ${ }^{28}$ Ami pedig az istenek szemében kedves embereket illeti, ${ }^{29}$ nem Até $^{30}$ hág a fejükre, hanem Athéna emeli magasba őket, és mint védőisten ${ }^{31}$ lép beléjük, híven születésének ismertetőjegyéhez.

[Az istennő magasztalása a tettei alapján] (8) Ebben áll az istennő égi és földi hatalma. ${ }^{32}$ Hogy mennyit ért, ér és fog érni az emberek és istenek szemében, arról az istenek gyermekei, Athéna karának tagjai jobban tudnának nyilatkozni, ${ }^{33}$ mégis meg kell próbálnunk valahogyan elmondani a megfelelő mértékig felhasználva a költőket ${ }^{34}$ és csak annyira engedni a beszédnek, hogy ne különbözzék sokban az álomtól, vagy pontosan egyezzen meg vele.

[Gigantomachia: Az istenek iránti jócselekedete] (9) Azt mondják, miután a

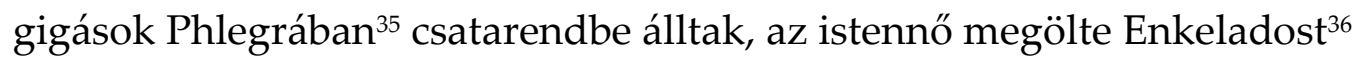
és a gigasok vezetőit. A többi istennek kevés teendőt hagyott, mert az istennő megölte a többi gigas közül a legerősebbet is, kiváltképpen azokat pusztította el, akik a természet szerint ellenségei voltak, mert az övével ellentétes fajból származtak. Ezek a föld üregeiből és a lehető legképtelenebb helyekről sarjadtak, míg az istennő az aithér a legtisztább részéből.

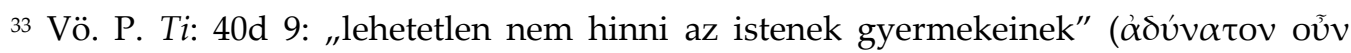
$\theta \varepsilon \tilde{\omega} \nu \pi \alpha \iota \sigma i v \alpha \dot{\alpha} \pi \iota \sigma \tau \varepsilon \tilde{\imath} v)$. Az istenek gyermekei a költőket jelenti. Aristeidés kiegészíti a platóni képet azzal, hogy párhuzamot von a költők és az istennő és a kartagok és karvezető között.

34 Ez szorosan összefügg a szónok mítoszokkal szembeni szkepszisével, erről ld. részletesebben GOEKEN (2012: 277-283).

35 Phlegra a gigantomachia mitikus helyszíne. Pl. A. Eum. 295, Pi. N. 1, 67 skk. Az orphikus himnuszokban Athéna a phlegrai gigasok elpuszítója ( $\Phi \lambda \varepsilon \gamma \varrho \alpha i ́ \omega v$ ò $\lambda \varepsilon ́ \tau \varepsilon \iota 0 \alpha$

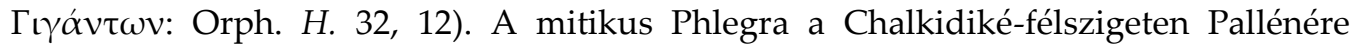
lokalizálható, vö. Hdt. 7, 123.

${ }^{36} \mathrm{Az}$ attikai mítoszváltozatban Enkelados Athéna ellenfele: 1d. pl. E. Heracl. 908. ill. az attikai vázákon olvasható kísérőfeliratokat. A legkorábbi darab egy, kb. a Kr. e. 6. század közepére datálható kismester-csésze, amelyen Athéna kerek pajzzsal, jobbjában lándzsával harcol Enkeladossal. A gigas nevét felirat jelzi, amelyet a sisakforgó felső részére írtak. A gigasok elleni harcban Athéna ellenfelei még pl. Berektas és Laertas: ehhez ld. a delphoi siphnosi kincstár frízét. Athéna ellenfelének azonosítása a pergamoni Zeus-oltár frízén vitatott. 


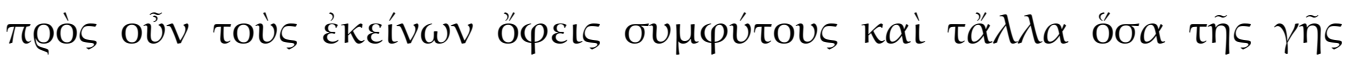

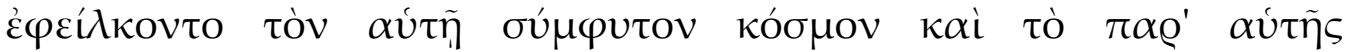

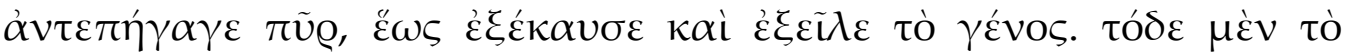

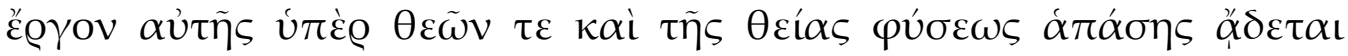

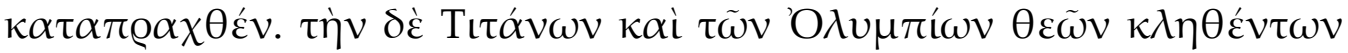

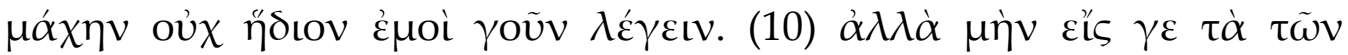

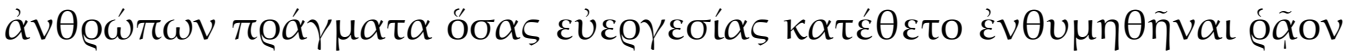

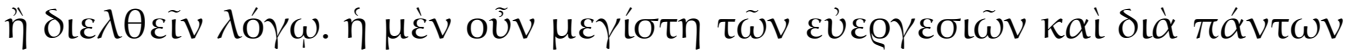

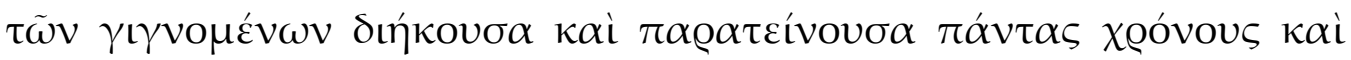

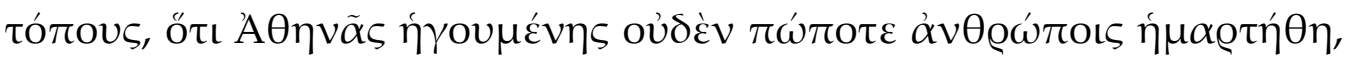

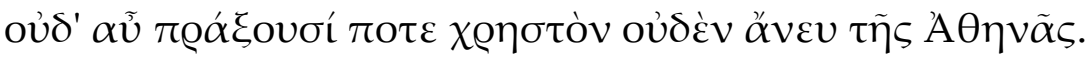

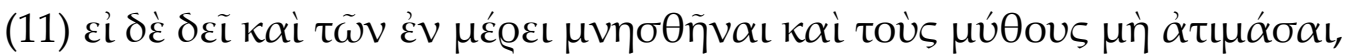

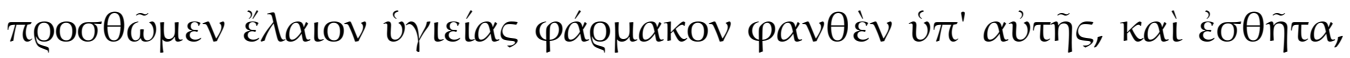

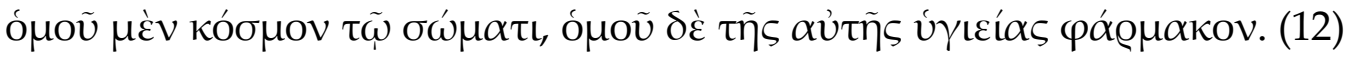

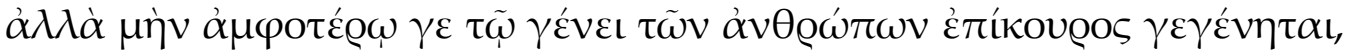

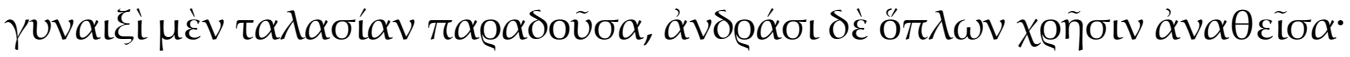

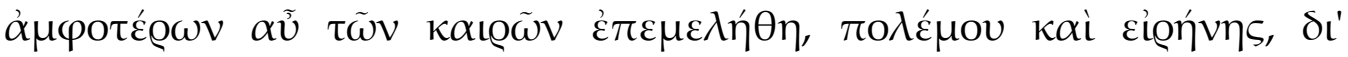

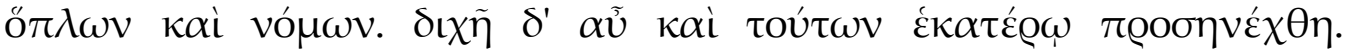

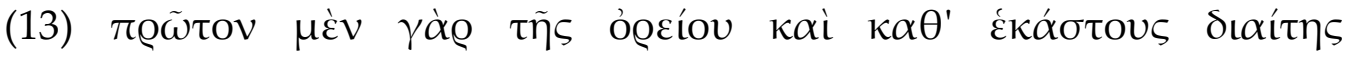

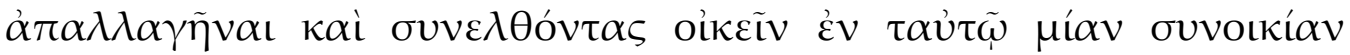

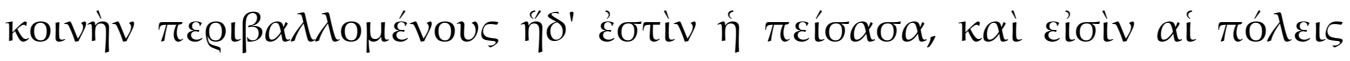

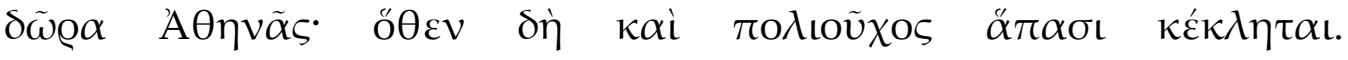

${ }^{37}$ Mind az irodalomban (Hes. Th. 186), mind a képzőművészetben a gigasokat először emberi alakban, hoplitákként ábrázolják. Kígyólábakkal - Typhón szkhémája nyomán először a Kr. e. 4. század vázafestészet ábrázolásain tünnek fel.

${ }^{38}$ Egyrészt Athéna dísze (vö. 3. caput: $\left.\kappa \circ \sigma \mu \eta \theta \varepsilon \tilde{\imath} \sigma \alpha\right)$, azaz vele született fegyverei, másrészt az Athéna által képviselt Rend áll szemben a gigasok által előidézett rendezetlenséggel.

${ }^{39}$ A gigasokat a tűz pusztítja el, éppúgy, mint Typhónt (Hes. Th. 853skk). A tüz összefügg az ekpyrósis sztoikus tanával is, azaz az eredeti tüzes állapotba való visszatéréssel. 40 A titánok felett aratott győzelem alapozta meg Zeus uralmát (Hes. Th. 624skk és 711skk). Athéna ehhez a harchoz nem tudott csatlakozni, hiszen még meg sem született.

${ }^{41} \mathrm{Az}$ istenség emberszeretete megint a himnuszok elmaradhatatlan eleme. Aristeidés is kitér erre a pontra valamennyi himnuszában.

${ }^{42}$ Itt Aristeidés a $\delta ı ́ \kappa o v \sigma \alpha . . . ~ \pi \alpha ́ v \tau \alpha \varsigma$ sztoikus formulát alkalmazza, hogy kifejezhesse Athéna egész emberi világot és történelmet érintő jócselekedetét. Allegorikus jelentésben Athéna mint phronésis („okosság”, „bölcsesség”) áthatol mindenen

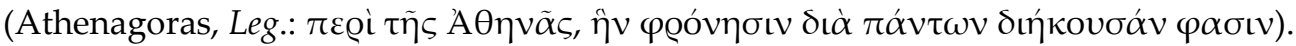

${ }^{43}$ Hes. Th. 429skk. 
Kígyólábaik ${ }^{37}$ és más, a földből magukkal hozott tulajdonságaik ellen Athéna a veleszületett ékességét ${ }^{38}$ és belőle áradó tüzet ${ }^{39}$ vetette be, amíg el nem égette és el nem pusztította e fajt. Megénekelték, hogy ezt a tettét az istenek és az egész isteni természet érdekében vitte véghez. Ezzel szemben a titánok és az úgynevezett olymposi istenek között dúló harc elbeszélése nem valami kellemes, legalábbis nekem. ${ }^{40}$

[Athéna jótéteményei az emberek irányában] (10) Az emberek életét érintő jótetteit ${ }^{41}$ könnyebb elképzelni, mint részletesen tárgyalni. A legnagyobb jótéteménye, mely kiterjed mindenre, ${ }^{42}$ ami csak megszületik, és minden időn és helyen átível, kétségkívül abban áll, hogy Athéna vezetése alatt az emberek vétkes dolgot nem múveltek sohasem, sem hasznos dolgot nem tesznek nélküle. ${ }^{43}$ (11) Ha a mítoszokat sem mellőzve részletekbe kell bocsátkoznunk, említsük meg az olajat ${ }^{44}$ mint az istennő által teremtett egészségmegőrző gyógyszert, és a ruházatot, mely egyszerre dísze a testnek és játszik szerepet az egészség megóvásában. ${ }^{45}$ (12) Mindkét emberi nemnek a támasza volt: az asszonyoknak a gyapjúfonást ${ }^{46}$ adta át, a férfiakra a fegyverek használatát bízta. A fegyverek és a törvények útján gondja volt mindkét állapotra - háborúra és békére egyaránt. Mindkét területnek kétféle módon is hasznára volt. (13) Athéna volt az első, aki meggyőzte az embereket, hogy hagyjanak fel az elszigetelt hegyi életvitellel, hogy gyüljenek egybe és éljenek ugyanazon a helyen, s hogy egyetlen közös településsel védelmezzék magukat. ${ }^{47} \mathrm{~A}$ városok tehát Athéna ajándékai, ezért nevezte mindenki „Városvédőnek" 48 az istennőt.

$44 \mathrm{Az}$ istennő Attika birtoklásáért Poseidónnal folytatott viszálykodása során nemesítette az olajfát. Az olaj egészségóvó szerepéhez ld. Pl. Mx. 238 a; Pi. P. 221skk.

${ }^{45}$ A ruha mint pharmakon: védi és befedi a csupasz testet. Ld. Pi. O. 9, 97sk.; Pl. Plt. 279e; Ph. Ex. 22, 25.

${ }^{46}$ Már a homéroszi eposzokban ebben a minőségben tűnik fel - peplosát is maga szövi: Hom. Il. 734sk. Athéna tanította szőni Pandórát is (Hes. Op.63sk). A phaiák asszonyok a szövőszéken végzett munkájukról voltak híresek (Od. 7, 110sk.)

47 A primitív, kezdetleges életforma negatívan jelenik meg. Aristeidés számára a civilizáció a synoikismosszal és az azzal járó társadalmi kapcsolatokkal kezdődik. Athéna volt az első, aki meggyőzte az embereket, hogy gyüljenek össze és alapítsanak városokat. 48 Athénát, a polisok védelmezőjét Athéna Polias, Poliatis, Politis, Poliouchos mellékneveken tisztelték. A Poliouchos azt a személyt jelöli, aki fellegvárat uralja, megtartja, egy istenséggel kapcsolatban állva védelmezi azt. Athénát megilleti a Poliouchos jelző, hiszen ő adományozta az embereknek a városokat. Trója védőistennője már a homérosi eposzokban is felbukkan (Hom. Il. 6, 269skk). 


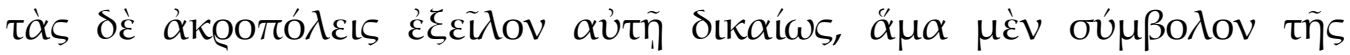

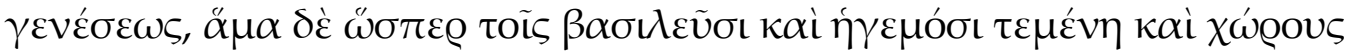

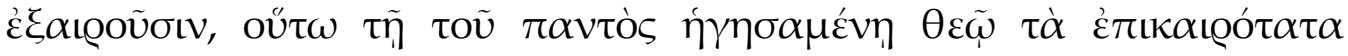

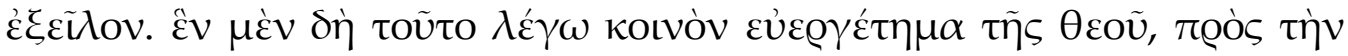

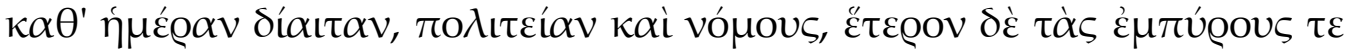

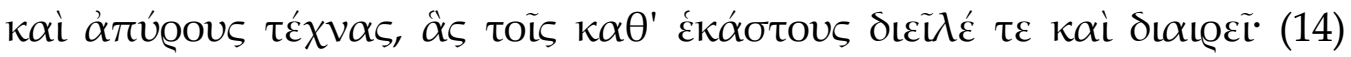

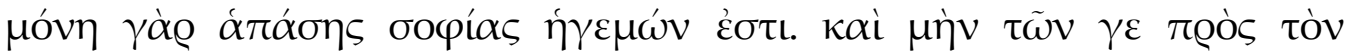

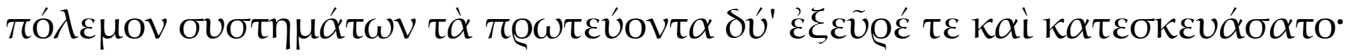

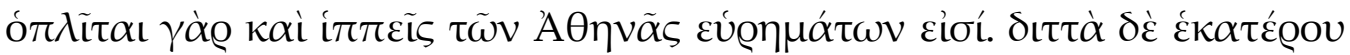

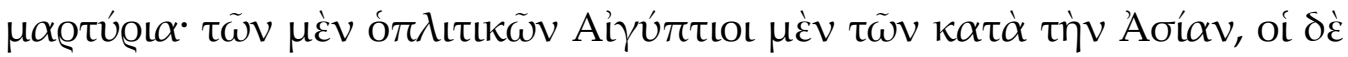

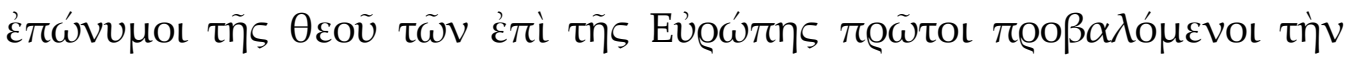

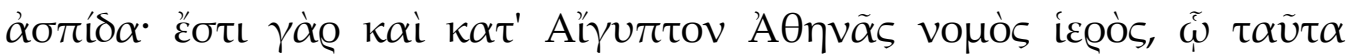

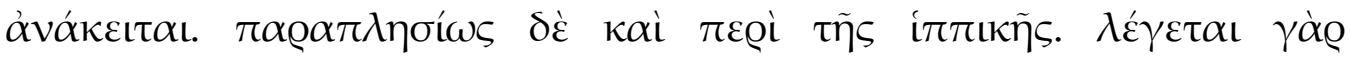

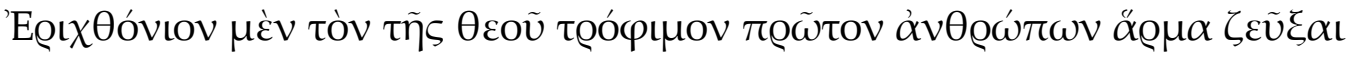

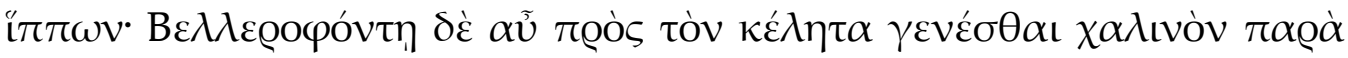

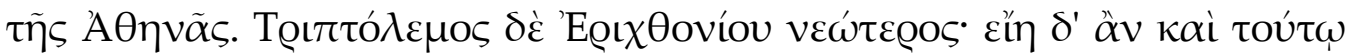

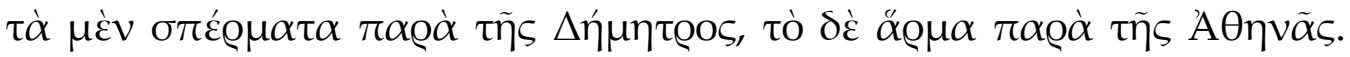

49 A temenos a homérosi eposzokban az istenség (Hom. Il. 2, 696; 8, 48; 23, 148) vagy hérós, uralkodó (Hom. Il. 6, 194; 9, 574skk) számára a közbirtokból sorsolás útján kihasított rész. Később a „szent kerület” jelentése válik elterjedté. Az aristeidési szövegben a temenos voltaképpen a királyoknak és hősöknek kijáró díszsír, ehhez ld. Hdt. 4, 161, 3.

${ }^{50}$ Vö. Pl. Grg. 450 c. és Pl. Prt. 321e 1-2.

${ }^{51}$ A hopliták felszerelését - a sisakot, pajzsot és a lándzsát - viselte Athéna is születése pillanatában.

${ }^{52} \mathrm{Az}$ athéniak, vö. Pl. Tim. 24 b 7.

53 Egyiptom Ázsiához sorolását és a világ kettéosztását (Ázsia, Európa) például Isokratésnél is megtaláljuk (Isoc. Paneg. 179).

${ }^{54} \tau \alpha \tilde{v} \tau \alpha$ ti. $\sigma v \sigma \tau \eta \dot{\mu} \alpha \tau \alpha$ (a hopliták múvészete).

55 Ehhez ld. Pl. Tim. 21 e. A Nílus nyugati deltájánál fekvő Sais főistene Neith, akit Athénával azonosítanak. Vö. Hdt 2, 169-170.

56 Erichthonios, Athén mitikus királya. Bizonyos mítoszvariáns szerint $\alpha u ̉ \tau o ́ \chi \theta \omega v$

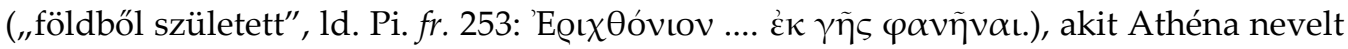
fel (Apollod. 3, 14, 6). A Kr. e. 5. századi attikai vázafestészetben közkedvelt az a jelenet, amikor Gé átnyújtja Athénának a csecsemő Erichthoniost.

Aristeidés nem említi, hogy Erichthonios Héphaistos fia. Héphaistos ugyanis megpróbálta megerőszakolni Athénát. Ám az istennő ellenállt, s dulakodásuk folyamán Héphaistos spermája Athéna combjára cseppent, aki undorodva letörölte egy gyapjúcsomóval (É@ıv) és a földre hajította $(\chi \theta \omega)$ ) azt. Erichthonios tehát a Földre csöppenő spermából született. 
Joggal szentelték neki az Akropolisokat, hiszen ez születésének szimbóluma, másrészt, ahogyan királyoknak és vezetőknek választják ki a szent körzeteket és helyeket, ${ }^{49}$ ugyanúgy szemelték ki a legalkalmasabb helyet a mindenség felett uralkodó istennőnek is. Szóval ezt tartom az istennő első közös jócselekedetének, ami a mindennapi életre vonatkozik - pontosabban az államrendre és a törvényekre. A második a tüzzel összefüggő és tűz nélküli mesterségekkel kapcsolatos. ${ }^{50}$ Ezeket az embereknek egyénileg osztotta szét és osztja még most is, mert egyedül ő a vezetője a bölcsesség egészének.

(14) Valójában a katonai alakulatuk közül az első kettőt is ő találta fel, majd szervezte meg: a hopliták ${ }^{51}$ és lovasság ugyanis Athéna találmányaihoz tartozik. Két bizonyítékot is találni erre. Ami a hoplitákat illeti, Ázsia népei közül az egyiptomiak, Európában az istennő után elnevezett város lakói ${ }^{52}$ voltak az elsők, ${ }^{53}$ akik maguk előtt pajzsot tartottak. Ráadásul Egyiptomban van egy Athénának szentelt szent tartomány is, melyhez ez a harci müvészet ${ }^{54}$ füződik. ${ }^{55}$ Hasonló a helyzet a lovassággal is. Úgy beszélik, hogy az istennő első neveltje, Erichthonios ${ }^{56}$ az első ember, aki kocsi elé fogta a lovakat. ${ }^{57}$ A hátaslóhoz Bellerophón Athénától kapta a zablát. ${ }^{58}$ Triptolemos, aki Erichthoniosnál fiatalabb, a magvakhoz Démétér, de a kocsihoz Athéna révén jutott. ${ }^{59}$

\footnotetext{
57 Athéna találta fel a harckocsit. Hom. Hymni 5, 12sk: „elsőként tanította az ácsokat a

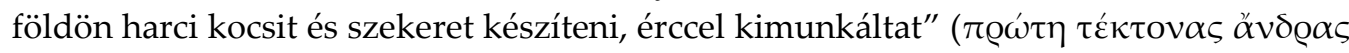

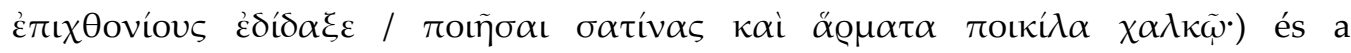
négyesfogatot is (Cic. ND 3, 59: quadrigarum inventricem).

58 Pi. O. 13: Athéna kantárjának köszönhetően Bellerophónnak sikerült befognia Pégasost, majd a hátasló segítéségével megölnie Chimairát. Pausanias arról számol be [Paus. 2, 4, 1], hogy „az istenek közül Athéna nyújtotta a legtöbb segítséget Bellerophontésznek, sőt állítólag ő adta neki a Pégaszoszt is: ő törte be a paripát, és

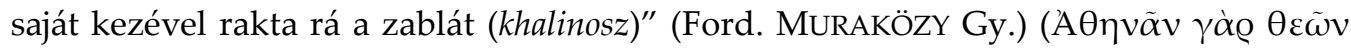

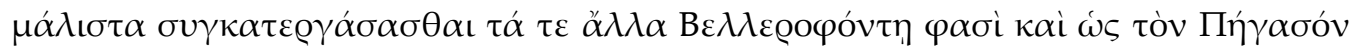

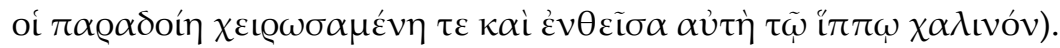

${ }_{59}$ Démétér Triptolemost választotta, hogy az embereket megtanítsa a földmúvelésre. Aristeidésnél Triptolemos csak az Athéna által feltalált kocsi révén tudta beutazni a világot. Démétér ajándékára csak Athéna adománya révén tehetett szert, a mezőgazdaság elterjedése tehát éppúgy Athénának is köszönhető.
} 


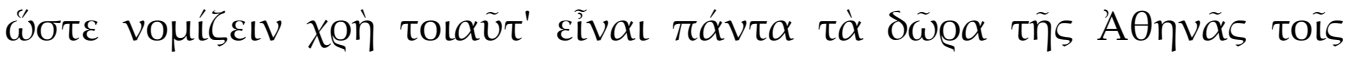

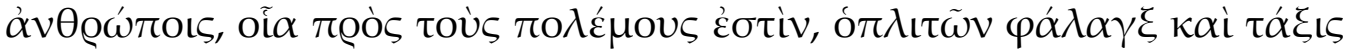

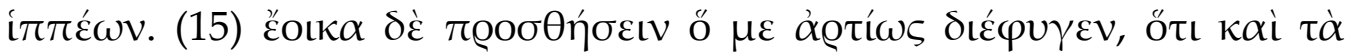

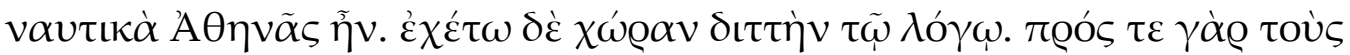

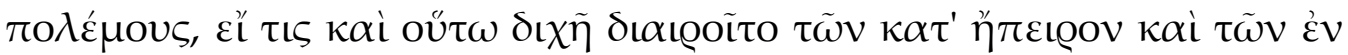

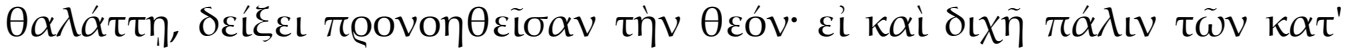

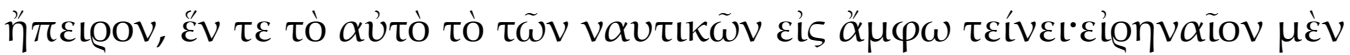

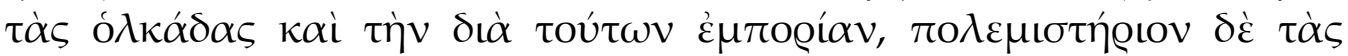

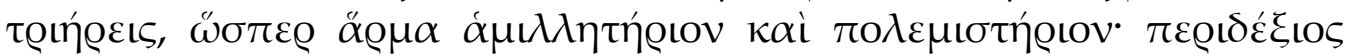

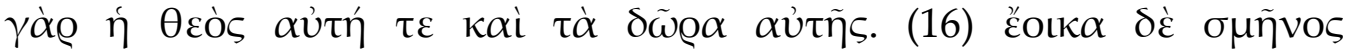

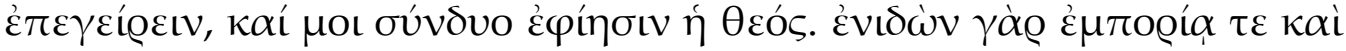

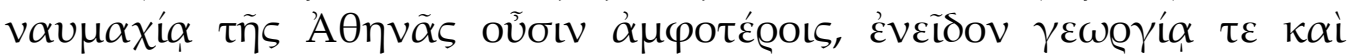

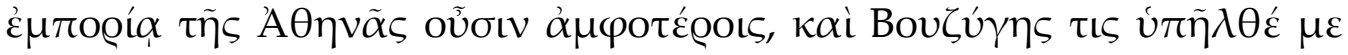

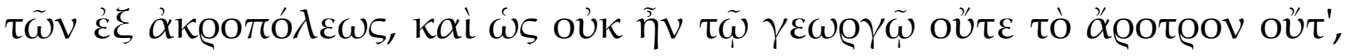

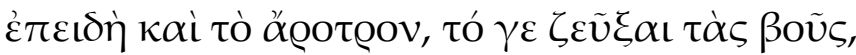

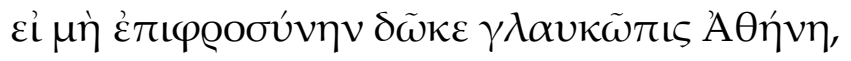

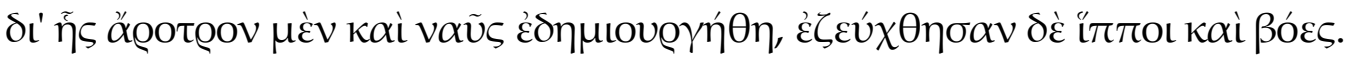

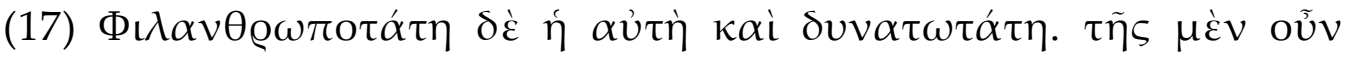

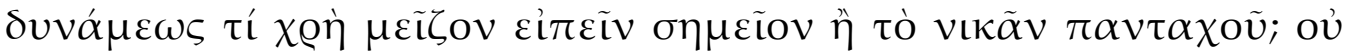

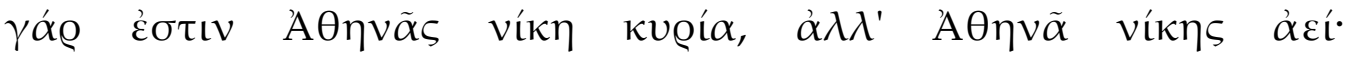

${ }^{60}$ Athéna kapcsolata a tengeri utazással és hajóval: a hajóépítés védnöknője (Hom. Il. 15, 410skk): „Ámde miként a zsinór megméri a gályagerendát / értő ács keze közt, aki mestersége tudását / bírja egészen, mert Pallas tanitotta meg arra." (Ford. DEVECSERI G.).

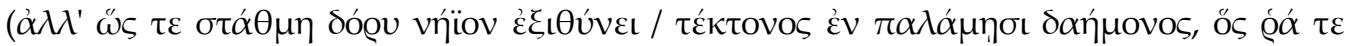

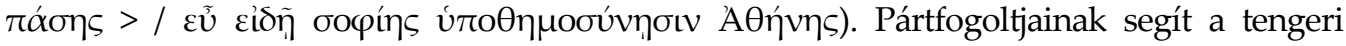

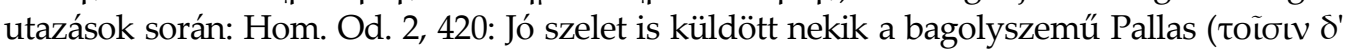

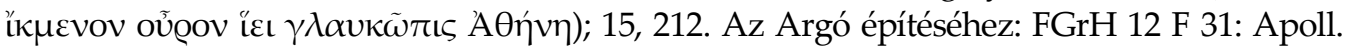
Rhod, 1, 18sk és 1, 111. Danaosnak a hajóépítésben nyújtott segítségéhez ld. Apollod. 2, 1, 4. ${ }^{61}$ A holkas vontatott hajó. A nyúlánk triérésszel ellentétben ez a hajótípus szélesebb és mélyebb. A kereskedelemben betöltött szerepe mellett csapatszállításra és utánpótlás biztosítására is használták.

${ }^{62}$ A triérés a Kr. e. 7. sz.- tól egészen a római korig használt harci evezős hajó. A korinthosiak legfontosabb találmánya: Th. 1, 13, 2.

${ }^{63}$ Utalás Sókratés egyik megnyilvánulására (Pl. Rep. 5, 450 b2).

${ }^{64}$ Athéni hérós, aki elsőként fogott be ökröket a szántáshoz. Azt is beszélik róla, hogy megszelídítette és kocsi elé fogta a bikákat. Ekéjét az Akropolison állították ki: Schol. ad. Aeschin. 2, 82.

${ }^{65}$ Hom. Od. 5, 437.

${ }^{66}$ Hes. Th. 383. 
Ezen a ponton meg kell jegyezünk, hogy Athéna embereknek szánt összes ajándékai ilyesfélék - a háborúhoz köthetők, mint a hoplita phalanx és a lovascsapat. (15) Úgy gondolom, kiegészítem azzal, amit eddig nem érintettem, tudniillik, hogy Athénának köszönhetően tettünk szert a hajózásra is. ${ }^{60}$ Ennek kétszeresen is helyet kell kapnia beszédemben: egyrészt mert fel fogja tárni, hogy az istennőnek gondja volt a háborúkra is, mégpedig ha ezt is további két részre osztjuk szárazon és vízen is. Bár a szárazföldi is kétfelé osztható, egy és ugyanaz a helyzet a hajózással, mely két területet ölel fel: békeidőben a vontatott teherhajót ${ }^{61}$ és az ezzel folytatott kereskedelmet, míg háború idején a triéreseket, ${ }^{62}$ éppen úgy, ahogy a verseny- és harci kocsik is két területet képviselnek. Az istennő éppoly leleményes, mint az ajándékai.

(16) Mintha csak méhkas bolydult volna fel, ${ }^{63} \mathrm{~s}$ ráadásul az istennő kettőt is küld nekem. Miután felismertem, hogy mind a (tengeri) kereskedelem, mind a tengeri hadviselés Athénától származik, majd beláttam, hogy a földmüvelés és a kereskedés is Athénától származik, s egy bizonyos Bouzygés ${ }^{64}$ jutott eszembe, egyike az Akropolisról származóknak, s hogy a földmúvesnek sem lett volna ekéje, de ha lett is volna, nem tudta volna befogni ökreit,

„ha nem adott volna bölcsességet a ragyogószemü Athéna." 65

Neki köszönhetően készült az eke és a hajó, s fogták igába a lovakat és az ökröket.

[Athéna emberszeretete és hatalma] (17) Athéna a lehető legemberszeretőbb és leghatalmasabb istennő. Szükséges-e annál nagyobb bizonyítékot említeni hatalmát illetően, minthogy mindenhol győzedelmeskedik? Mert nem a Győzelem ${ }^{66}$ Athéna úrnője, hanem Athéna áll mindig a Győzelem felett. ${ }^{67}$

${ }^{67}$ Ld. a himnusz 26-os caputját: „Nincs más az égilakók között, de egyáltalán a világon sem, akinek nevéhez nemcsak hozzájárul a győzelem, hanem neve egyenesen azonos azzal.” Athéna Niké kultusza leginkább Athénben ismert, kultusza Kr. e. 566-ig nyúlik vissza. Az Akropolison Kr. e. 420 körül épült meg Athéna Niké ión stílusú temploma (Vö. Pausanias pontatlanságával [Paus. 1 , 22 , 4]: ő ugyanis Niké Apteros, a Szárnyatlan Győzelem templomának nevezi). Kultusza Attika mellett Megarában (Paus. 1, 42, 4), a régészeti adatok alapján Rhodoson és Erythraiban is dokumentált. Pergamonban Athéna a háború istennője, aki szavatolja a győzelmet, epiklésise Niképhoros („Győzelemhozó”). A Niképhoros melléknév nem ősi kultusznév, hanem egy klasszikus müalkotásra, Pheidias Athéna Parthenos szobrára utal, ami jobb kezében a Győzelemistennőt tartotta. 


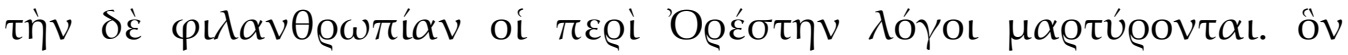

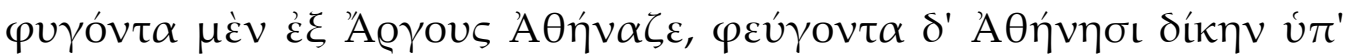

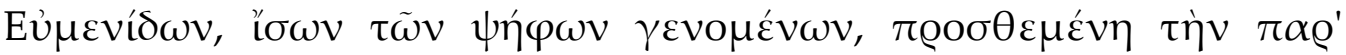

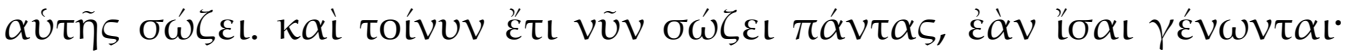

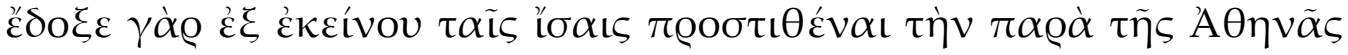

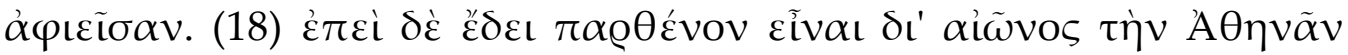

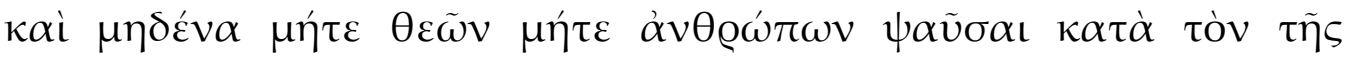

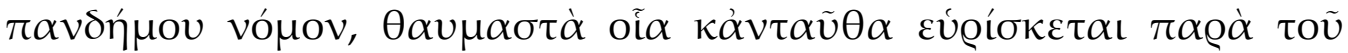

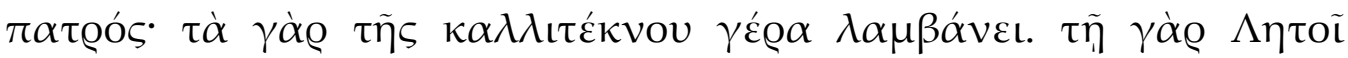

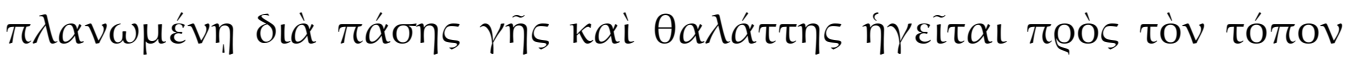

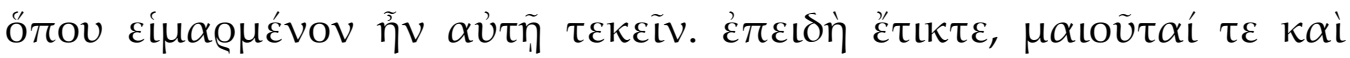

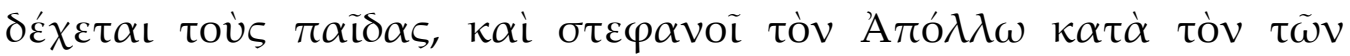

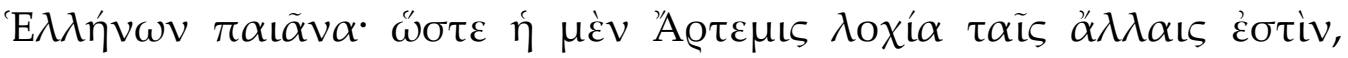

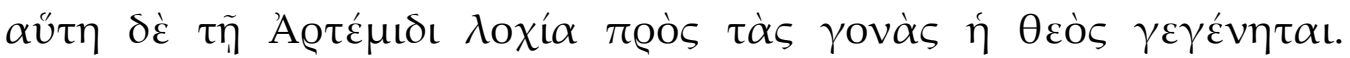

68 Aristeidés az aischylosi dráma változatát követi. Az Eumenisekben Orestést Athéna szavazatával fel is mentik a bünösség alól: A. Eu. 734skk.

${ }^{69}$ Athénát Sóteira („Megmento””) melléknévvel is tisztelték. Vö. A. Eu. 754: „Ó Pallas,

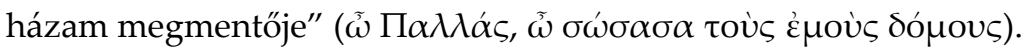

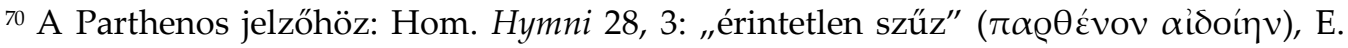
Tro. 971: $\pi \alpha \varrho \theta \varepsilon ́ v o v ~ \tau \varepsilon ~ \Pi \alpha \lambda \lambda \alpha ́ \delta \alpha$. Aphrodité - Artemis és Hestia mellett - Athénát se

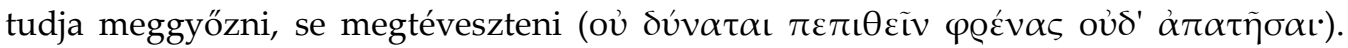
Hom. Hymni 5, 7 skk.

${ }^{71}$ Pandémos: „egész népet érinto"”, ,„általános.” Aphrodité epiklésise, a testi örömök istennője. Ehhez ld. Pl. Smp. 180 e, 1: a platóni Lakomában Pausanias Aphrodité Urania, az „Égi” Aphrodité és a testi örömöket megtestesítő Aphrodité Pandémos (lat. Venus Vulgivaga vagy Popularis) között tesz különbséget. Élisben felállított kultuszszobraihoz ld. Pausanias leírását (Paus. 6, 25, 1): „A templomban lévő istenszobor Pheidiasz alkotása, és Aphrodité Urániának nevezik. Elefántcsontból és aranyból készült, s egyik lábával egy teknősbékán áll. Aphrodité területe fallal van körülvéve, benne egy talapzatot emeltek, ezen áll Aphrodité bronzszobra egy bronzból készült kecskebakon. Ez Szkopasz müve, és Aphrodité

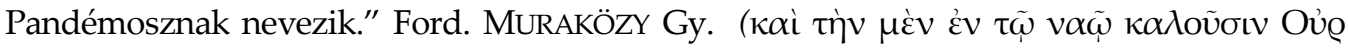

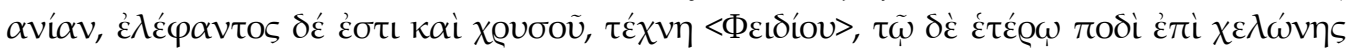

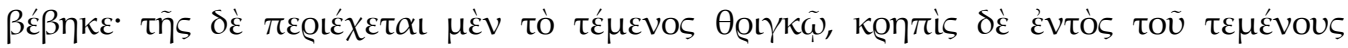

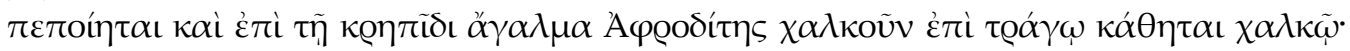

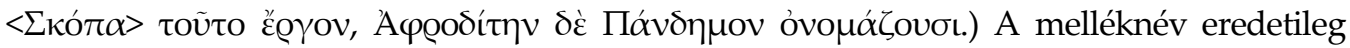
politikai jelentéssel is bírt, mert Aphrodité Pandémos a polis lakosságát egy társadalmi és politikai közösséggé is kovácsolja. Temploma az athéni agorán állt, a hagyomány szerint Solón építette a hetairák pénzéből (Paus. 1, 22, 3.) Aphrodité Pandémos kultusza Arkadiában és Thébaiban is közismert volt. 
Az istennő emberszeretetéről az Orestésről szóló beszámolók ${ }^{68}$ tanúskodnak: miután Orestés Argosból Athénba menekült, Athénban az Eumenisek bevádolták. Ám a szavazás eredménye döntetlen lett, és az istennő, hogy megmenthesse, ${ }^{69}$ Orestésre szavazott. Egyébiránt Athéna még most is mindenkit megóv, ha a szavazatok száma döntetlen, mert attól fogva határoztak úgy, hogy azonos szavazatszámok esetén bevezetik az Athénától érkező felmentést.

[Athéna kapcsolata a többi istennel] (18) És mivel Athénának örökké tartó szüzességet ${ }^{70}$ kellett fogadnia, Pandémos ${ }^{71}$ törvénye értelmében sem isten, sem ember nem érinthette. Ebben a helyzetben apja miféle csodát eszelt ki! Athéna a szép gyermekkel megáldott istennő előjogait kapja meg. A minden földet és tengert bebolyongó Létót Athéna vezette arra a helyre, ahol a sors elrendelte neki a szülést. ${ }^{72}$ A szülésnél Athéna bábáskodott, s örömmel fogadta a gyermekeket, sőt meg is koszorúzta Apollónt a hellének paianjának ${ }^{73}$ megfelelően. Artemis felügyeli mások születését, ${ }^{74}$ a mi istennőnk pedig Artemis születésénél volt segítő. ${ }^{75}$

\footnotetext{
72 Létó bolyongásához és Apollón születéséhez Déloson: Hom. Hymni 3, 31skk., 91skk.; Pi. Pae. 12 sskk és Call. Del. 55skk.

73 A $\pi \alpha \iota \bar{\alpha} v$ Apollónnak szánt hálaadó vagy győzelmi ének (Hom. Il. 22, 391skk.). Homéros szerint az istenek orvosának a neve (Hom. Il. 5, 401, 899; vö. Pi. P. 4, 270). A

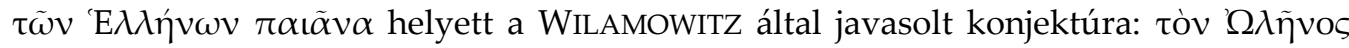
$\pi \alpha \iota \tilde{\alpha} v \alpha$. A mitikus lykiai költőhöz, Ólén alakjához ld. Hdt. 4, 35, 1.

74 Artemis Lochia: Artemis a legfontosabb születésistennő Eileithyia mellett. A születéssel kapcsolatos melléknevei: Lochia, Lechó, Eileithyia. Ld. Pl. Tht. 149 b: Airíav

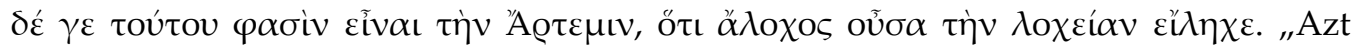
beszélik, hogy ennek az oka Artemis, mert osztályrésze a bábáskodás, noha ő maga nem szül."

75 A szűz Athéna összekapcsolása a szüléssel és a házassággal nem gyakori. Ld. pl. Athéna Anya (Métér) templomát Élisben (Paus. 5, 3, 2); a troizéni hajadonok házasságuk előtt övüket Athéna Apatouriának ajánlották fel (Paus. 2, 33, 1). Erichthonios dajkájaként és az istennőt sikertelenül ostromló Héphaistosról ld. 56. jegyzetet. Ezenkívül ld. Cic. ND 3, 55.: Apollón Patróos szülei Athéna és Héphaistos (Volcani item complures: primus Caelo natus, ex quo et Minerva Apollinem eum cuius in tutela Athenas antiqui historici esse voluerunt).
} 


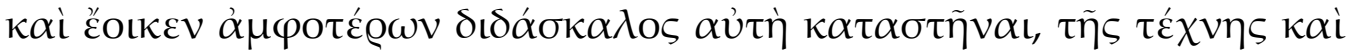

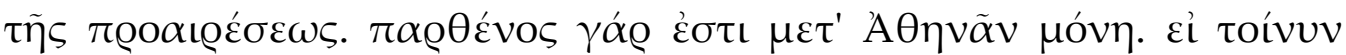

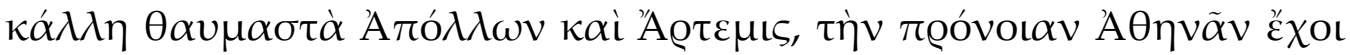

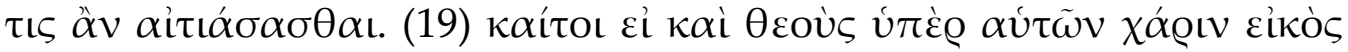

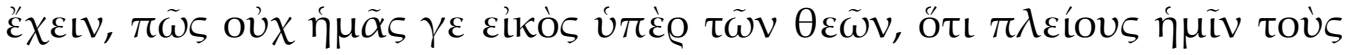

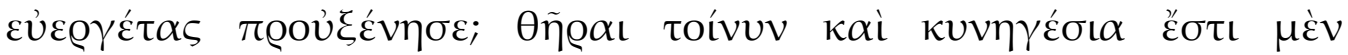

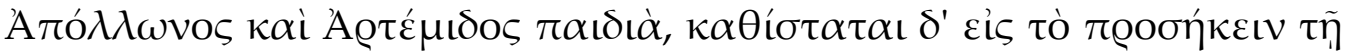

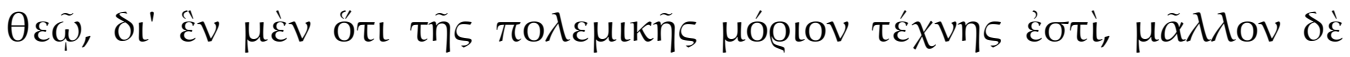

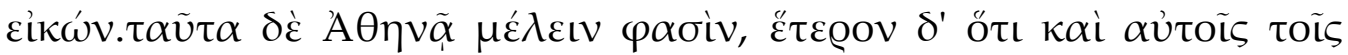

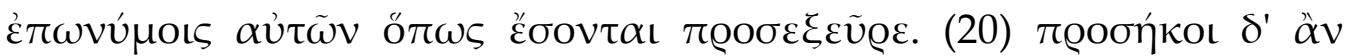

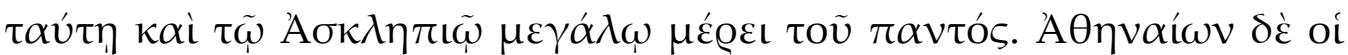

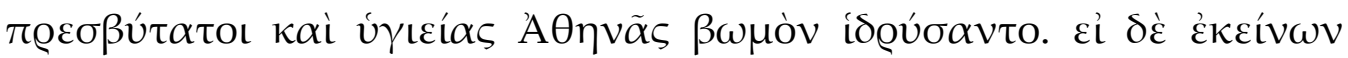

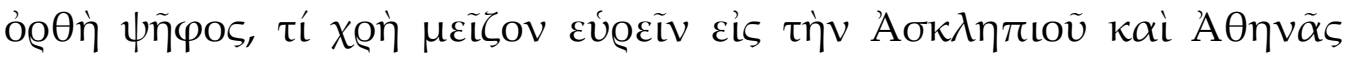

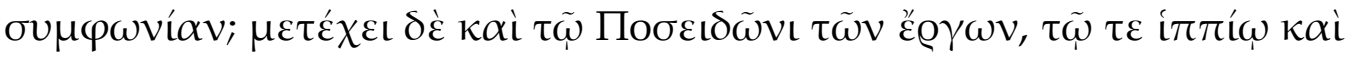

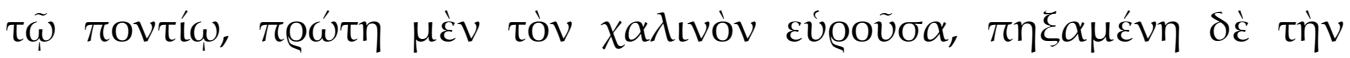
$\pi \varrho \omega ́ \tau \eta \nu ~ v \alpha \tilde{v} v$.

\footnotetext{
${ }^{76}$ Artemis gondolkodásmódjáról: Alc. fg. 44a: „Artemis az istenek nagy esküjét tette: a

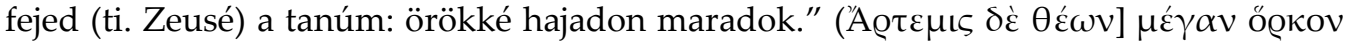

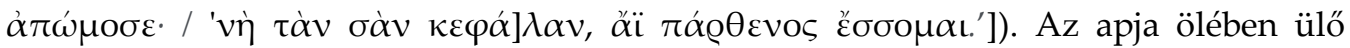
gyermek Artemis kérése: Call. Dian. 6.: „Ó papa, hadd őrizzem meg hajadonságomat

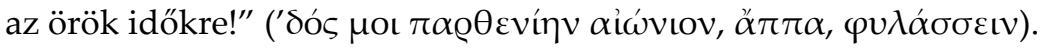

77 Az istennő Pronoia epiklésise Létó gyermekeiről való gondoskodással függ össze. Vö. Suda s.v. Athéna Pronoia: „egyesek (szerint azért nevezték így), mert delphoi temploma előtt állt (Pronoia: pro = előtt + naos = templom), míg mások szerint azért,

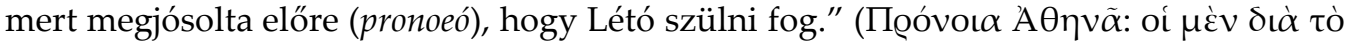

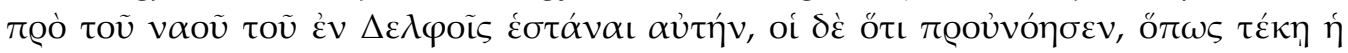
$\Lambda \eta \tau \omega ́$.

${ }^{78}$ Athéna azáltal, hogy Apollón születésénél segédkezett, az isten fiához, Asklépioshoz is kötődik. Athéna kultusza Tegeában kapcsolódik össze Asklépiosszal és Hygieiával: ld. Paus. 8, 47, 1. Az istennő Asklépios iránti rokonszervéhez, tudniillik, hogy neki ajándékozta a Gorgó ereiből kifolyt vért ld. az Apollodórosnál fennmaradt hagyományt (Apollod. 3, 10).
} 
Úgy tünik, két dolgot is megtanított Artemisnek - a művészetét és a gondolkodásmódját, ${ }^{76}$ hiszen Artemis Athéné után az egyedüli szűz istennő. Ha tehát Apollón és Artemis a szépség csodái, ezt egyedül a "Gondviselő" Athénának tulajdoníthatjuk. ${ }^{77}$

(19) Ha még az isteneknek is természetes, hogy köszönetet mondanak, amiért ők tartoznak az istennőnek, hogy ne lenne természetes nekünk az istenek irányába megtenni ugyanezt, hiszen a legtöbb jótevőt Athéna biztosította számunkra? Ugyan a hajsza és a vadászat Apollón és Artemis időtöltése, mégis Athénához vezethető vissza, mert része, jobban mondva mása a háború művészetének. Márpedig az elbeszélések szerint ezek Athéna hatókörébe tartoznak, másrészt még azt is az istennő találta ki, hogy az ő nevük fogja fémjelezni e tevékenységeket.

(20) Ekképpen Asklépioshoz is nagymértékben kapcsolható. ${ }^{78}$ Athén legősibb lakói Athéna Hygieiának is oltárt emeltek. ${ }^{79}$ Ha elgondolásuk helyes, kell-e erősebb bizonyíték Asklépios és Athéna kapcsolatára? Az istennő azonban kiveszi a részét Poseidón, a lovak és tenger istenének munkáiból is, hiszen Athéna az első, aki feltalálta a zablát és megépítette az első hajót. ${ }^{80}$

\footnotetext{
79 Athéna Hygieia athéni kultusza a Kr. e. 5. sz. második negyedig nyúlik vissza: ld. Pl. Per. 13, továbbá a Propylaia mellett talált bázison olvasható feliratot: „Az athéniak

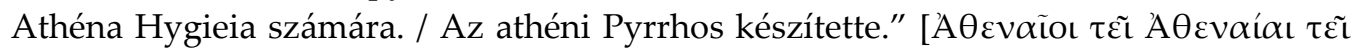

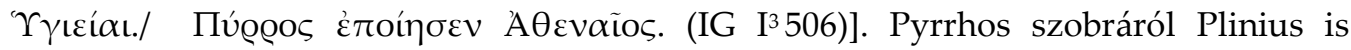
beszámol (HN 34, 80): Pyrrhus Hygiam et Minervam (...).

80 Athéna kiveszi a részét Poseidón Hippias és Pontios tevékenységeiből is (vö. Hom. Hymni. 21, 4sk: „Ó Földrázó, kettős tisztet adtak az istenek / hogy lovakat szelídíts

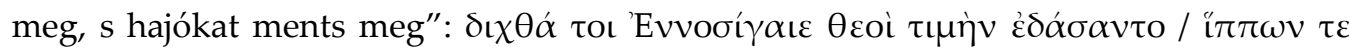

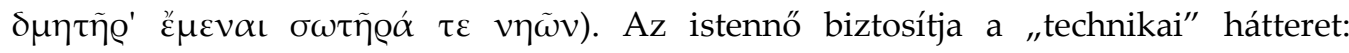
megtanította Erichthoniosnak befogni a lovakat, Bellerophónnak zablát adott Pégasos megszelídítéséhez (ld. a himnusz 14. caputját); a tengerhez pedig a hajóépítés révén kötődik (ld. 15. caputot).
} 


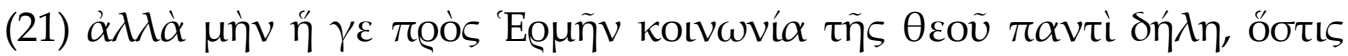

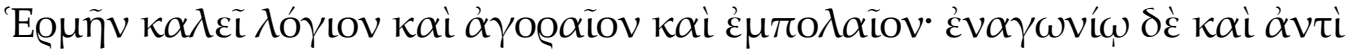

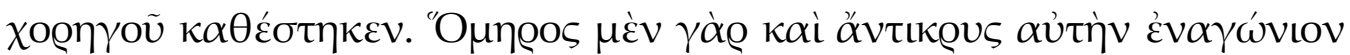

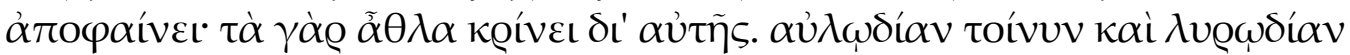

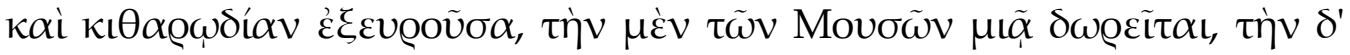

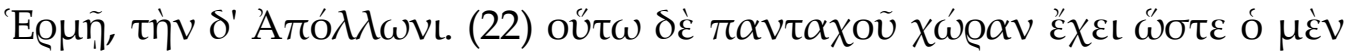

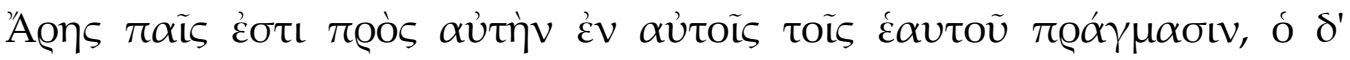

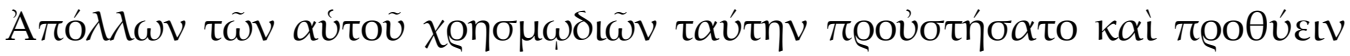

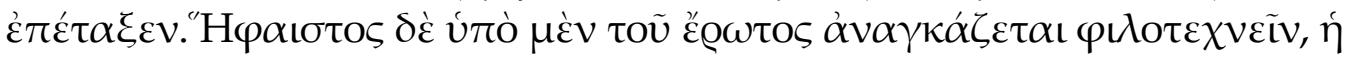

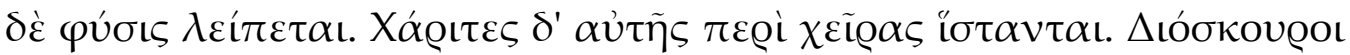

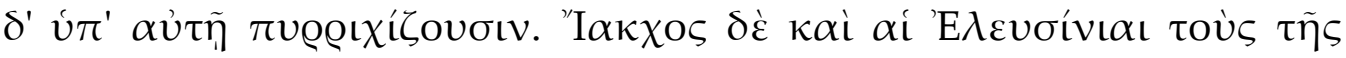

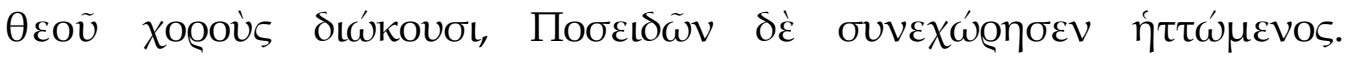

${ }^{81}$ Hermés Logios: Pl. Cra. 408b: „a Hermés név valamiképpen a beszédre kell hogy vonatkozzék ... nevezzétek azt, aki a beszédet kitalálta (eirein emészato), Eiremésznek."

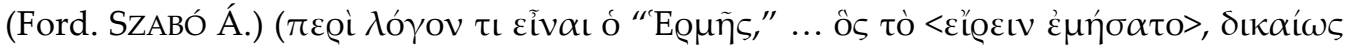

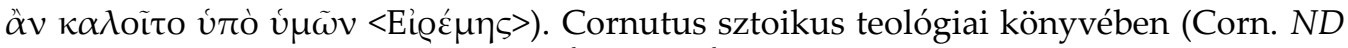
16) azt írja, hogy Hermés a Logos (Értelem, Ész), „akit az istenek küldtek hozzánk az

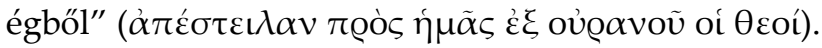

${ }^{82} \mathrm{Az}$ Agoraios vagy Agoraia epiklésist Athéna mellett Artemis, Aphrodité, Themis, de a leggyakrabban Zeus és Hermés viseli. Hermés Agoraios bronzszobra az athéni agorán állt a Stoa Poikilé nyugati oldala előtt (Paus. 1, 15, 1). Athén mellett Sikyónban (Paus. 2, 9, 8), Spártában (Paus. 3, 11, 11), Thébaiban és Boiótiában (Paus. 2, 9, 8), az achaiai Pharaiban (Paus. 7, 22, 2), a feliratos emlékek alapján többek között Déloson, Imbroson és Erythraiban is ismert volt.

${ }^{83}$ Az Empolaios melléknévhez ld. Ar. Ach. 816; Pl. 1155. Kultusza Rhodoson is ismert,

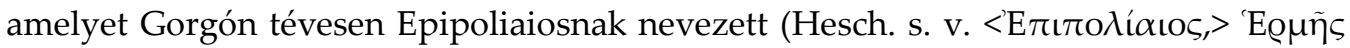

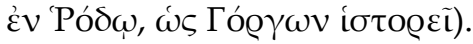

${ }^{84}$ Athéna karvezetôvel való azonosításához ld. előzményként az isteni kar élén álló Zeust (Pl. Phdr. 246e).

${ }^{85}$ Enagónios, Agónios („Versengő”): Hermés a zenei és sportversenyek védelmezője. A legkorábbi, Hermés Enagóniosra vonatkozó adat egy eleusisi feliraton olvasható a Kr. e. 5. század elejéről. Az olympiai stadion bejáratánál állt az oltára.

${ }^{86}$ Vö. Hom. Od. 8, 193-198

${ }^{87}$ Talán Euterpé vö. Hor. C. 1, 1, 32-33: si neque tibias / Euterpe cohibet.

${ }^{88}$ Egy boiót legenda szerint Athéna találta fel a fuvolát. Pindaros (Pi. P. 12, 6skk és 19) úgy mondja el, hogy Athéna lemásolva a Gorgók jajgatását találta fel az auloit ( $(\alpha \lambda \lambda \dot{\alpha} \varsigma$

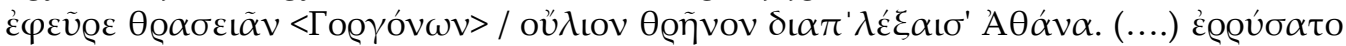

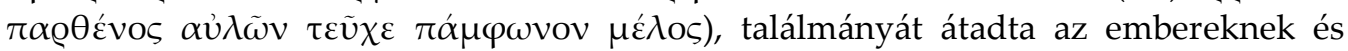

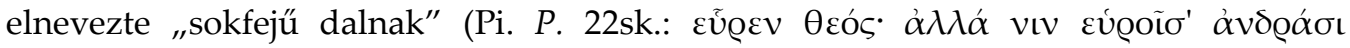

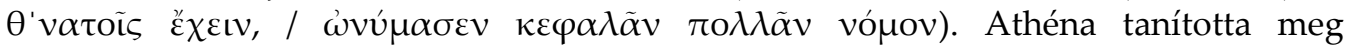
Apollónnak a fuvolajátékot is (Corinn. fr. 17). 
[Athéna szerepe a költőknél] (21) Továbbá az Athéna és Hermés közötti kapcsolat is mindenki előtt világos, aki csak Hermést az "Ékesszóló", ${ }^{81}$ „Vásárt védő" 82 és a „Kereskedést kedvelo"” 83 jelzővel illeti: az istennő mint chorégos $^{84}$ is feltünik, amikor Hermés a versenyjátékokat felügyeli. ${ }^{85}$ Homéros egyenesen Athénát a versenyek védőistennőjeként nevezi, mert Hermés a versenyeket az istennőnek köszönhetően bírálja. ${ }^{86} \mathrm{~A}$ fuvola-, lyraés kitharakísérettel előadott dalt is Athéna találta fel: ezeket a múzsák egyikének, ${ }^{87}$ Hermésnek, s Apollónnak ajánlotta fel. ${ }^{88}$ (22) Olyannyira megvan a helye mindenhol, hogy Arés csak gyermek hozzá képest még a harci tetteiben is. ${ }^{89}$ Apollón saját jósdája védelmezőjévé tette az istennőt és meghagyta, hogy legelőbb az ő tiszteletére mutassanak be áldozatot. ${ }^{90}$ Héphaistost iránta érzett vágya veszi rá, hogy szeresse múvelni müvészetét: természete ugyanis alacsonyabb rendü. ${ }^{91} \mathrm{~A}$ Charisok ${ }^{92}$ Athéna keze intésére állnak körbe, a Dioskourosok ${ }^{93}$ az ő vezetésével járják harci táncukat. Tiszteletére Iakchos ${ }^{94}$ az eleusisi istennőkkel körtáncot lejt, de még Poseidón is elismerte az istennőt, bár alulmaradt vele szemben. ${ }^{95}$

Ezenfelül Apollod. 1, 4, 2: Marsyas, miután megtalálta azt a sípot, amit Athéna dobott el, zenei versenyre kelt Apollónnal, e jelenetnek a képzőművészetben való megjelenéséhez ld. a Myrón által készített Athéna-Marsyas szoborcsoportot (Paus. 1, 24; Plin. HN 34, 57).

89 Aristeidés alig méltatja Arést, vö. 6. caputtal.

90 Athéna Pronoia temploma Delphoiban: Hdt. 1, 92, 1; 8, 37,2. A Pronoia magyarázatához ld. a Suda-lexikon szócikkét a 77. jegyzetben.

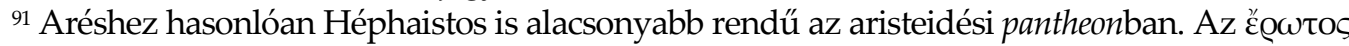

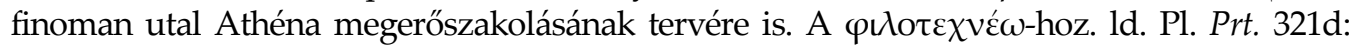
„Athéna és Héphaistos közös lakába, ahol ezek ketten együtt gyakorolják szeretett

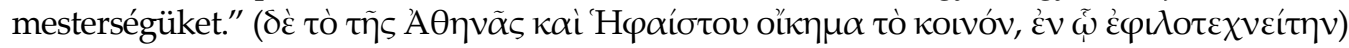
${ }^{92}$ A Charisokat az istennővel Athénben, Boiótiában, Erythraiban és Kyzikosban hozták kapcsolatba. Athén vonatkozásában: Paus. 1, 22, 8; 9, 35, 2. A Gráciák felemlegetésével egy kevésbé zord kép bontakozik ki az istennőről.

${ }_{93}$ A Dioskourosok is engedelmeskednek Athénának. A halikarnassosi Dionysios által

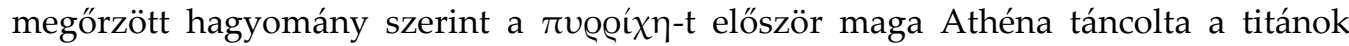
(valójában a gigasok) feletti győzelem során,vö. D. H. 7, 72, 7.

${ }^{44}$ Démétér kísérője, az eleusisi misztériumok egyik istensége. Szorosan kapcsolódik a mystések Athénból Eleusisba tartó processiójához, különösen a körmenet résztvevőinek rituális síráshoz (i $\alpha \chi \eta$ ). Iakchost általában fiatalemberként, a kettős fáklyáját tartva, Démétér, Persephoné, Hekaté és más eleusisi istenség társaságában ábrázolják. Iakchost Dionysos istennel is azonosították - különösen a tragikusok: ld. S. Ant. 1152; E. Ion 1074-1077.

${ }_{95}^{5}$ Utalás az Athéna és Poseidón Athén birtoklásáért folyó vetélkedésére. A legkorábbi irodalmi beszámoló ld. Hdt. 8, 55. A legkorábbi képzőmüvészeti ábrázoláshoz ld. a Parthenón nyugati oromcsoportját. 


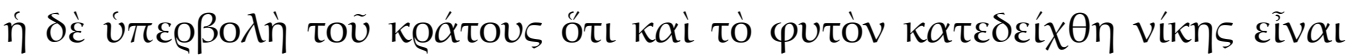

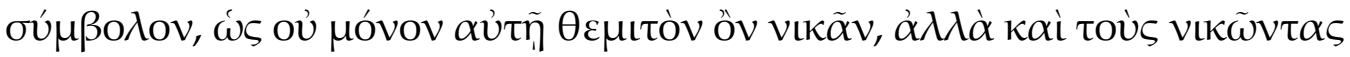

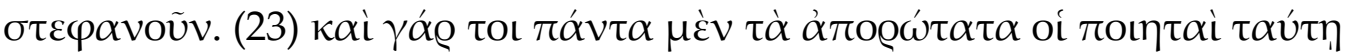

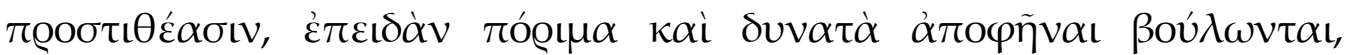

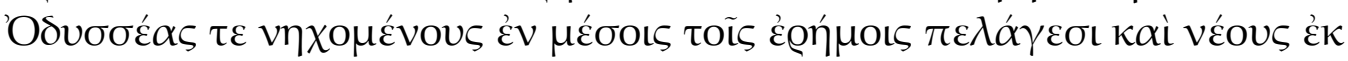

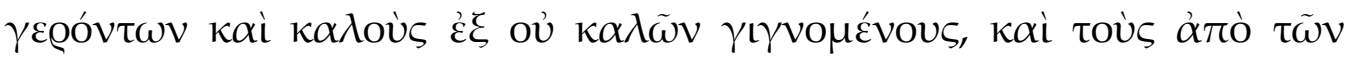

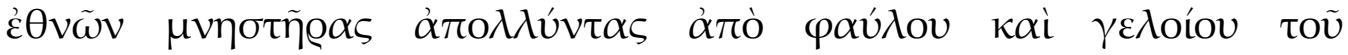

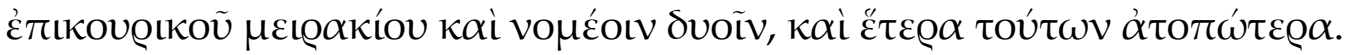

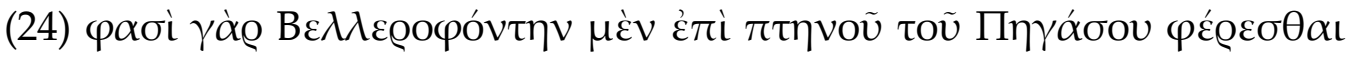

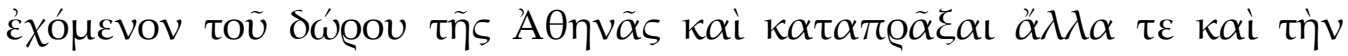

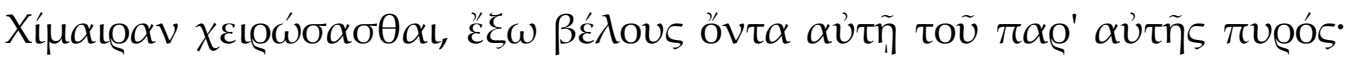

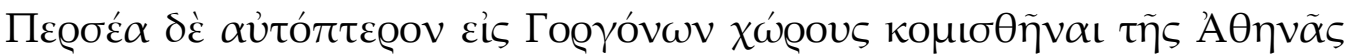

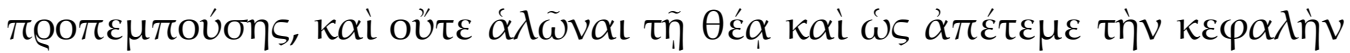

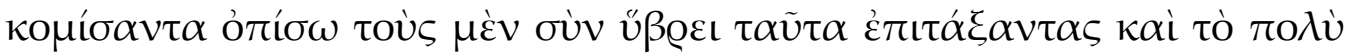

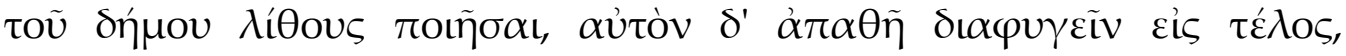

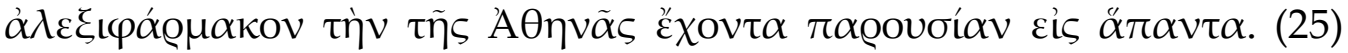

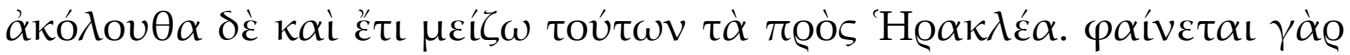

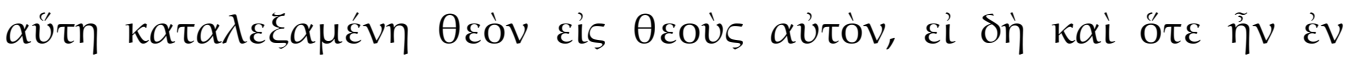

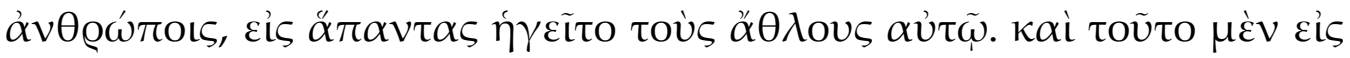

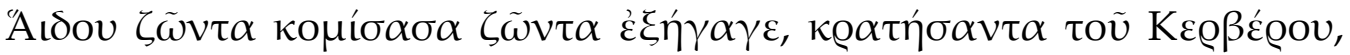

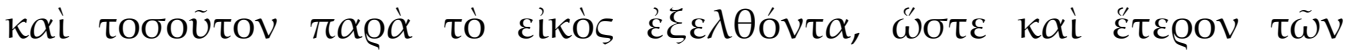

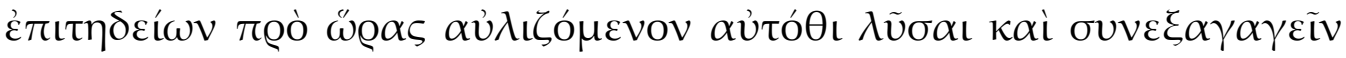

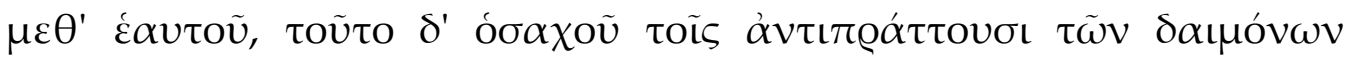

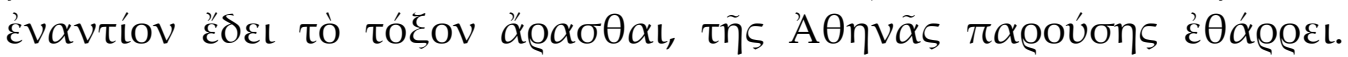

${ }_{96}$ Olajfa ágaiból font koszorúval jutalmazták az olympiai versenyszámok győzteseit. Vö. Ar. Pl. 585.sk

97 Vö. Hom. Od. 5, 374-425: Inó-Leukothea fátyollal segít a tengeren hánykódó Odysseusnak.

98 Vö. Hom. Od. 6, 229-237: Athéna erőt és dalias külsőt ad Odysseusnak; 16, 172-176: Athéna, megérintve aranypálcájával, charisszal övezi körbe Odysseust.

99 Vö. Hom. Od. 22, 1-329: A kérők megölésében Odysseust fia, Télemachos és két pásztor - Eumaios és Philoitios - segítette.

100 Pontosabban Pégasos megszelídítéshez a kantárt, amit a szerző már a 14. és 20. caputban is említett.

${ }_{101}$ Chimairához ld. Hom. Il. 6, 181sk.; Hes. Th. 319; Pi. O.13, 90.

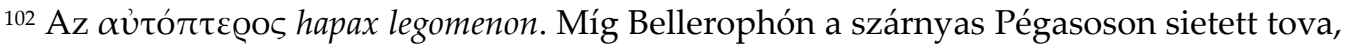
Perseusnak szárnyas saruja volt. Vö. Luc. DMar. 14, 2: a hős Athénától kapja a szárnyas

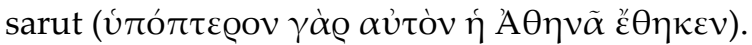


Mérhetetlen hatalma megnyilvánul abban, hogy még növényét is a győzelem jeleként ismerték el, mert az isteni törvény nem csupán a győzelmet rendelte hozzá, hanem a győztesek megkoszorúzását is. ${ }^{96}$ (23) S a költők is, amikor a lehető legkilátástalanabb helyzeteket megoldhatónak és lehetségesnek akarják beállítani, az istennőre bízzák: akadnak náluk Odysseusok, akik az elhagyatott tenger kellős közepén úsznak; ${ }^{97}$ az öregböl ifjúvá, rútból daliássá változnak, ${ }^{98}$ megölik az idegen kérőket egy serdülő ifjú és két pásztor nevetségesen csekély segítségével, és más, ezeknél is abszurdabb helyzetek. ${ }^{99}$

(24) Azt mesélik, hogy Bellerophónt a szárnyas Pégasos vitte, amit Athéna ajándékul szánt neki, ${ }^{100}$ egyebek mellett még Chimairát is legyőzte, mert kívül esett tüzének hatótávolságán. ${ }^{101}$ Perseus pedig saját szárnyain ${ }^{102}$ ment a Gorgók földjére Athéna kíséretében, ${ }^{103}$ kitért Medúza tekintete elől, ${ }^{104} \mathrm{~s}$ miután levágta fejét, visszavitte és kővé dermesztette a gonosz parancsosztókat és a nép nagy részét, ${ }^{105}$ és végül épségben megmenekült, mert Athéna jelenléte minden helyzetben oltalmat biztosított számára. ${ }^{106}$ (25) Nem marad el emögött, sőt még figyelemre méltóbb, ahogy Héraklésszel bánik. Nyilvánvaló, hogy ez az istennő volt, aki felvette Héraklést az istenek közé, hiszen amíg az emberek között időzött, addig is Athéna vezette valamennyi munkájánál. ${ }^{107}$ Egyrészt élve levitte Hadésba, s a Kerberos legyőzése után ugyanúgy ki is vezette onnan - sőt mi több, egyik társát, ${ }^{108}$ aki idő előtt került oda, megszabadította és magával vitte. Másrészről Athéna a jelenlétével bátorította, valahányszor íjat kellett emelnie azon istenségekre, akik ellene akartak tenni.

\footnotetext{
${ }^{103}$ A Gorgók lakhelyének pontos lokalizálásához ld. pl. Hes. Th. 274sk, Apollod. 2, 4, 2; Hdt. 2, 91,6.

${ }^{104}$ A Gorgók kővé dermesztik, aki csak rájuk pillant. Perseus a pajzsát használta, hogy kitérjen Medúza tekintete elől, így sikerült végeznie vele.

105 Polydektés, Seriphos királya, Perseustól Medúza fejét követelte ajándékként, mert Hippodameiával, Oinomaos leányával készül menyegzőt tartani. A hérós engedelmeskedett neki, de visszatérve a levágott Gorgó-fővel kővé változtatta a királyt és a seriphosiakat (Apollod. 2, 4, 2).

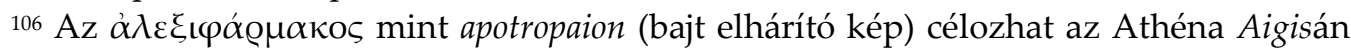
látható Gorgó-főre is: Hom. Il. 5, 741.

107 Athéna már Homérosnál is segíti Héraklést: Hom. Il. 8, 362.

${ }^{108}$ Utalás Théseusra. Vö. Verg. Aen. 6, 617 sk: sedet aeternumque sedebit / infelix Theseus (...).
} 


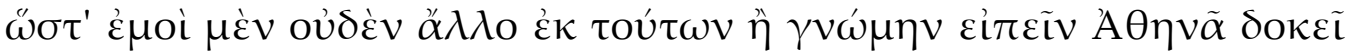

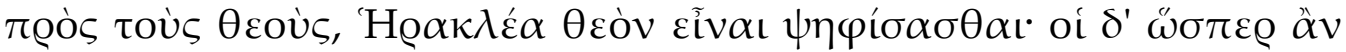

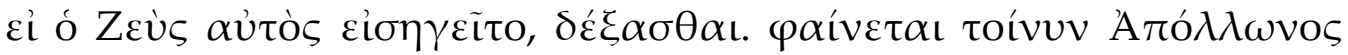

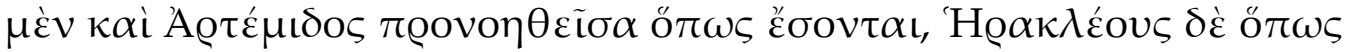

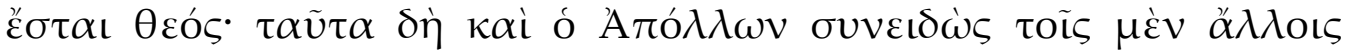

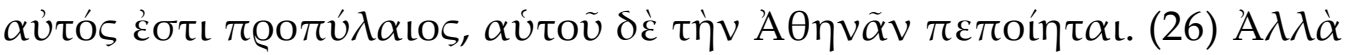

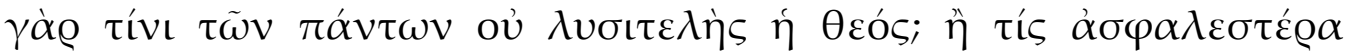

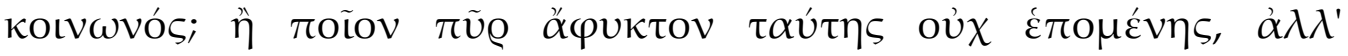

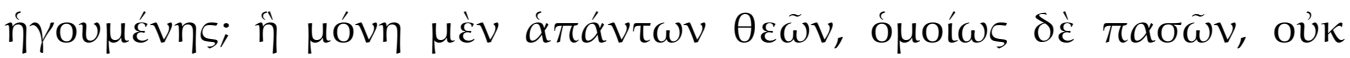

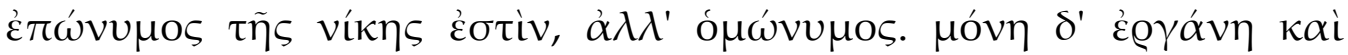

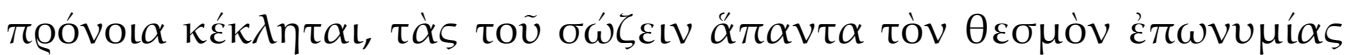

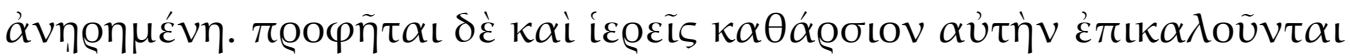

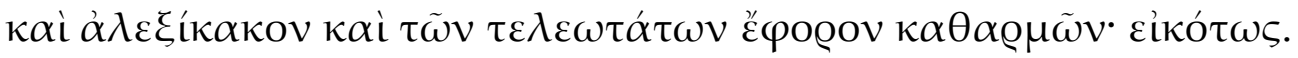

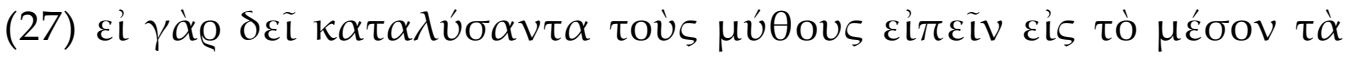

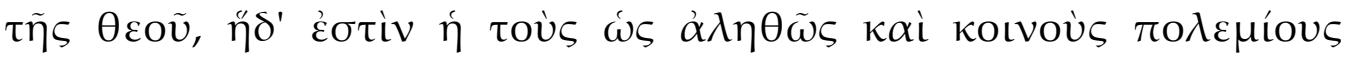

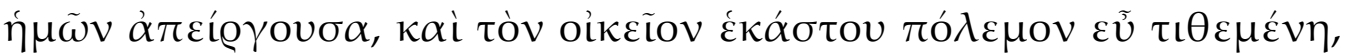

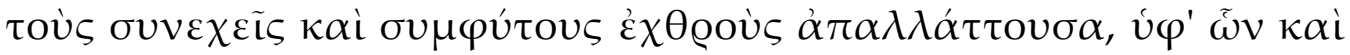

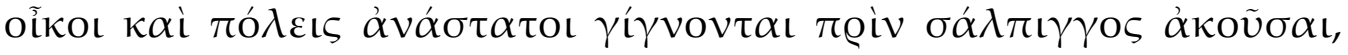

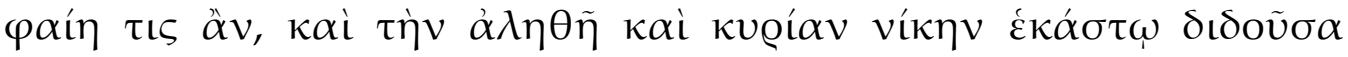

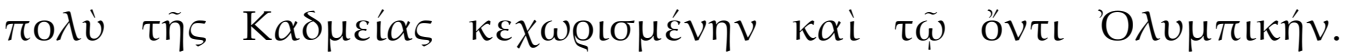

${ }^{109}$ Héraklés Olymposra való felvételét ábrázolták az athéni Akropolis régi Athénatemplomának keleti oromzatán is. Továbbá ld. az amyklai-i Apollón trónusát Paus. 3, 18,11 és 19,5 .

110 A Theos Propylaios funkciója a szentélyek, házak és városkapuk védelme. Apollón kívül a Propylaios/Propylaia jelzőt Hermés, Hekaté, Artemis, Poseidón, Athéna viseli.

111 Utalás a tüzet okádó Chimairára vagy KEIL olvasatában a tüz itt a summum malumot jelöli.

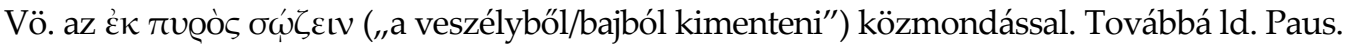
Gr. „tüzet tűzre (hordani): közmondás, amiről Platón is megemlékezik, azaz bajt bajra”

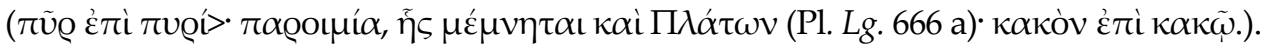

112 Ergané: a mesterségbeli tudás és mesterségek védelmezője. Ebből kiindulva Ergatis, Machanitis, Ergoponos, Polyergos nevekkel is illették. Tiszteletéhez ld. pl. Paus. 1. 24 és 3, 3, 17,4. Továbbá Suda s.v. Ergané: „Athéna jelzője abban a tekintetben, hogy ő felügyeli a nők munkáját. Így hívják őt az athéniak és samosiak is. A szó még a munkát

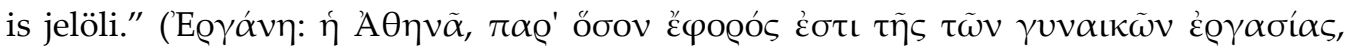

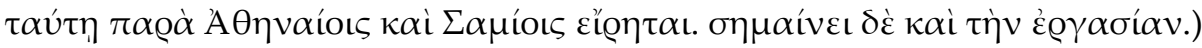

${ }^{113}$ Utalás Athéna Sóteirára, 1d. 69. jegyzetet.

114 Azaz a költők, vö. Aristid. Or. 45, 4. 
Ebből nem tudok másra következtetni, mint hogy Athéna indítványozta, hogy az istenek szavazzák meg Héraklés megistenülését. ${ }^{109}$ Ők pedig, mintha maga Zeus javasolta volna, bele is egyeztek. Úgy tünik tehát, hogy amint előre kigondolta Artemis és Apollón majdani születését, úgy Héraklés jövőbeni istenné válását is. Ezt Apollón is jól tudta, $\mathrm{s}$ ahogy más istenek szempontjából ő a „Kapu előtt álló”, 110 úgy a maga előtt Athénát tette azzá.

[Athéna melléknevei] (26) Ugyan kinek nem válik hasznára ez az istennő? Akad-e nála megbízhatóbb segítőtárs? Ha Athéna nem csupán kísérő, hanem vezet is, van-e tüz, amelyből lehetetlen szabadulni? ${ }^{111}$ Nincs más az égilakók között, de egyáltalán a világon sem, akinek nevéhez nemcsak hozzájárul a Győzelem, hanem neve egyenesen azonos azzal. Egyedül őt illették a „Dolgozó"112 és a „Gondoskodó" nevekkel, megkapott minden, az isteni rend megőrzésével ${ }^{113}$ kapcsolatos melléknevet is. A jósok ${ }^{114}$ és a papok „Megtisztító"115 és „Bajelhárító”, ${ }^{116}$ a „Legteljesebb megtisztulás őre” jelzőkkel is illetik. Teljes joggal.

[Athéna szimbolikus értelmezése] (27) Ha a mítoszok mellőzésével kell feltárnom az istennő lényegét, ${ }^{117}$ akkor ő az, aki távol tartja tőlünk valódi közös ellenségeinket, elcsitít minden belső háborút is, elüzi a köröttünk sűrűn támadó ellenségeinket, akik feldúlják otthonainkat és városainkat: mondhatni már mielőtt felharsannak a harci kürtök, ${ }^{118}$ Athéna mindenkinek valódi, s a Kadmoséra még csak hírből sem emlékeztető győzelmet oszt, ${ }^{119}$ mely valóban olymposinak nevezhető.

115 A Katharsios melléknév egyedül itt fordul elő az istennővel kapcsolatban, amely Orestés megmentésére és büntől való megtisztítására vonatkozik. Az Alexikakos melléknévvel együtt apotropaikus funkciója van.

116 Aristeidésnél az Alexikakos jelzőt elsősorban Héraklés viseli: Aristid. Or. 40, 15. Athéna Alexikakoshoz 1d. a 106. jz-et, továbbá Athéna Apotropaia és Zeus Apotropaios kultuszát Lindoson, Erythraiban, továbbá a Forum Romanum egyik

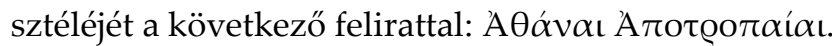

117 Aristeidés innentől elhagyja a mítoszok világát, a költői beszámolókat, és Athéna szimbolikus értelmezésére tér rá.

118 A csatákban a salpinx megfújásával adtak jelt a támadásra: Hom. Il. 18, 219.

119 A „kadmosi győzelem” - a pyrrhosi győzelemhez hasonlóan - kárba veszett, haszontalan győzelemre vonatkozik, amely a győzteseknek több veszteséget okoz, mint maguknak a legyőzötteknek Hdt. 1, 166,2. 


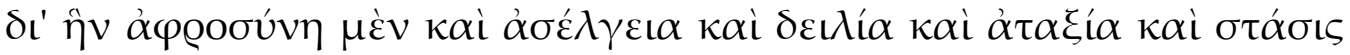

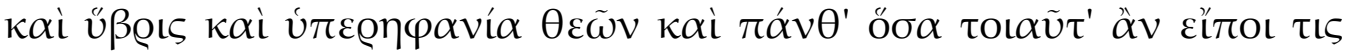

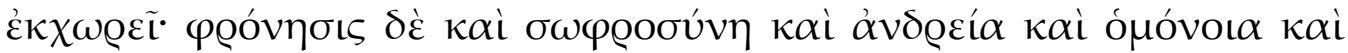

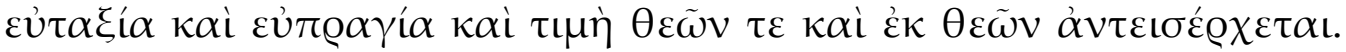

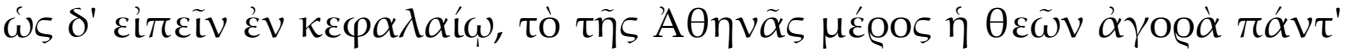

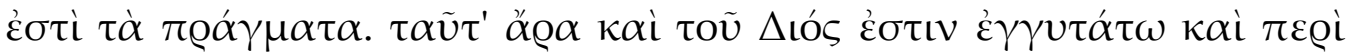

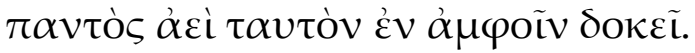

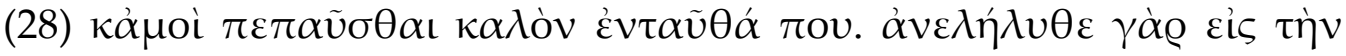

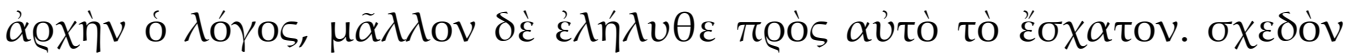

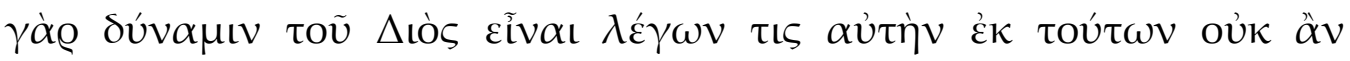

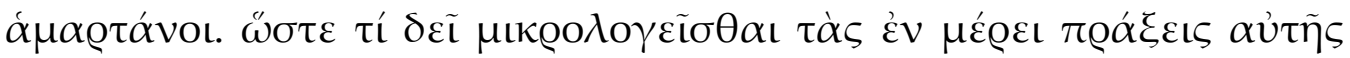

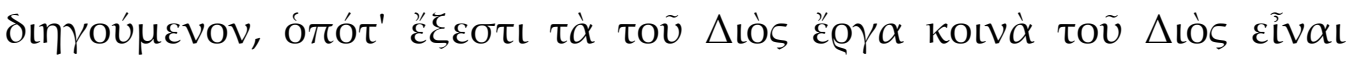

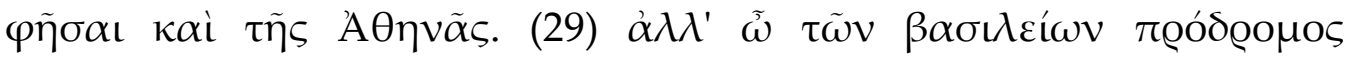

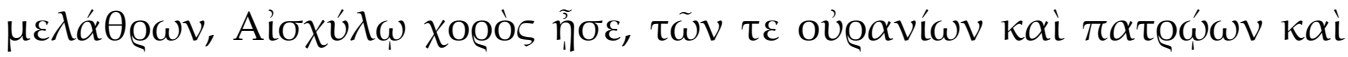

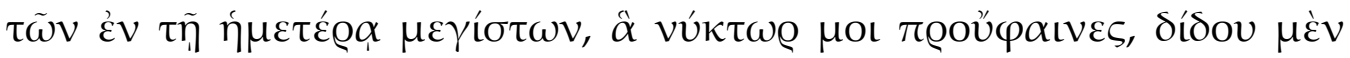

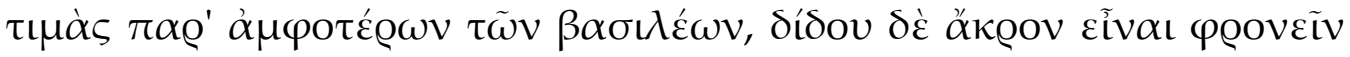

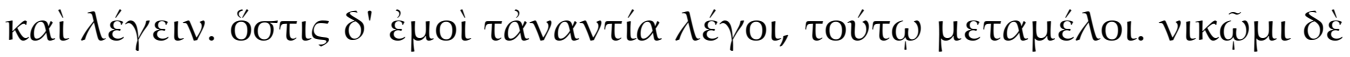

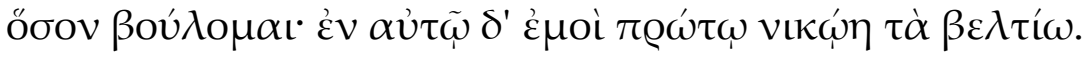

120 Aristeidés dynamis-fogalma a sztoikus tanításból táplálkozik. A Stoában a dynamis fogalmával az "egy” istenség különféle aspektusai írhatók le. Vö. Pl. Corn. ND 20: "Athéna Zeus intelligenciája, ugyanolyan, mint az istenben lakozó gondviselés" (H $\delta \dot{\varepsilon}$

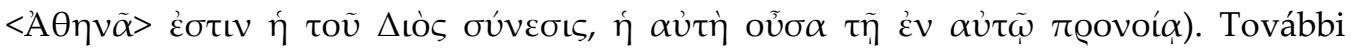
párhuzamokhoz: JÖHRENS (1981, 1 kötet: 185-188).

${ }^{121}$ Aischylos egy nem azonosítható tragédiában nevezte így Hekatét: Schol. Theoc. 2, 36 (fr. 388)

122 Itt egyértelművé válik Athéna álmokat adó szerepe, vö. az 1. caputtal. 
Neki köszönhetően szünik meg az esztelenség, a féktelenség, a gyávaság, a rendetlenség, a viszály, a gőgösség, az istenekkel szembeni önteltség és még hosszan sorolhatnánk. Helyükbe lép a bölcsesség, a higgadtság, a bátorság, az egyetértés, a rend, a jó cselekvés és a tisztelet mind az istenek irányába, mind a részükről. Röviden: Athéna érdeme, hogy az istenek gyưlésének mindenre kiterjedő befolyása van. Éppen ezért áll Athéna a legközelebb Zeushoz, s ez mindkettejük esetében mindennel kapcsolatban kitünik.

[Athéna mint Zeus ereje] (28) Jó, ha valahol itt állok meg, hiszen gondolatmenetem visszakanyarodott a kiindulópontjához vagy inkább a végéhez ért. Ha valaki ezekből a magyarázatokból arra a következtetésre jutna, hogy többé-kevésbé Athéna Zeus ereje ${ }^{120}$ egyáltalán nem tévedne. Miért kell tetteit részletesen megvizsgálni és sorban előadni, ha kijelenthetjük, hogy Zeus tettei egyúttal Zeus és Athéna közös tettei?

[Záró könyörgés] (29) Ámde „ó előfutára királyi palotáknak,"121 miként a kar Aischylosnál énekelte, melyek az égiek, ősiek, s e mostaniak közt a legnagyobbak, add meg nekem azt, amit az éjjel megmutattál: ${ }^{122}$ megbecsülést mindkét császártól,123 adj kimagasló bölcsességet és ékesszólást! Bánja meg, aki ellentmond nekem! Győzzek, valahányszor akarok, de elsőként bennem magamban győzzön a jobb. ${ }^{124}$

${ }^{123}$ A két császár Antoninus Pius és Marcus Aurelius, mivel a beszéd Kr. u. 152. decemberében vagy 153. januárjában keletkezett, erről ld. GOEKEN (2012: 347-348).

124 Egyes kéziratokban a himnusz szövege a következő subscriptioval végződik: „Aristeidéstől Athéna istennőnek, Barisban Severus proconsulsága alatt, 35 éves és 1

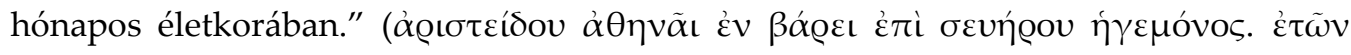

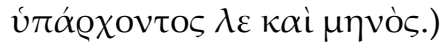

